\title{
Structure and nutrient transfer in a tropical pelagic upwelling food web: From isoscapes to the whole ecosystem
}

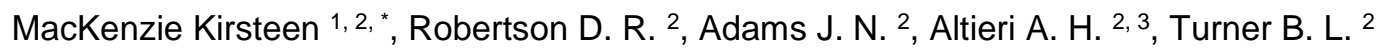

${ }^{1}$ Inst Marine Res, Hjalmar Johansens Gate 14, N-9007 Tromso, Norway.

2 Smithsonian Trop Res Inst, Panama City, Panama.

3 Univ Florida, Gainesville, FL 32611 USA.

* Corresponding author : Kirsteen MacKenzie, email address : kirsteen.mackenzie@gmail.com

\begin{abstract}
:
Little is known about ecosystem structure and nutrient flux in the pelagic zone of seasonal upwelling systems in the tropics, despite their global importance to marine production. The Tropical Eastern Pacific (TEP) is responsible for around $10 \%$ of global ocean productivity, largely due to wind-driven seasonal upwelling areas between Mexico and Panama. The Gulf of Panama has a detectable outflow for hundreds of kilometres into the Pacific Ocean and the upwelling system there is an important productivity source in the TEP. In this study, we aim to determine the spatio-temporal patterns in variability of carbon and nitrogen stable isotope composition throughout the pelagic ecosystem of the Bay of Panama in upwelling and non-upwelling conditions, and how these patterns are recorded throughout the ecosystem from primary producers to apex predators. We characterise the stable isotope composition of basal production in the ecosystem to quantify spatial variability during the non-upwelling season. We use the delta $\mathrm{N}-15$ composition outside of upwelling season as an ecosystem baseline and quantify the overall delta $\mathrm{N}-15$ separation between all trophic levels $(T L)$ from primary producers to apex predators (e.g. yellowfin tuna and mahi mahi) within the pelagic ecosystem $(2.9+/-0.1$ parts per thousand per TL). The ecosystem has a relatively simple, linear structure with size-based TL increase. We calculate the predator-prey mass ratio of this ecosystem (c. 113:1 for fishes, 376:1 for the whole ecosystem, uncertainty range: 77:11272:1). These values are low for existing estimates in other marine ecosystems, although within the expected range for animals of the mass sampled. The calculated predator-prey mass ratios and maximum TL indicate that this pelagic ecosystem may have a relatively long trophic chain, with inefficient nutrient transfer from low to high TLs.
\end{abstract}

Using a monthly time series of stable isotope values of resident, planktivorous fishes and co-occurring sea surface temperature measurements, we determine nutrient transfer time between primary production and TL3 fish. We calculate a rapid nutrient turnover time within this ecosystem as 0.5-1 month per TL. The incorporation of upwelled nutrients, which are enriched in the $\mathrm{C}-13$, leads to higher consumer delta C-13 values. Carbon isotopes can therefore be used to track timing, duration, and use of upwelling zones. Our findings give novel, empirical insights into the functional ecology of the pelagic ecosystem in the Gulf 
of Panama, and provide a baseline for comparison and quantification of ecosystem structure and dynamics in the tropics, and in other pelagic upwelling systems. 
The Tropical Eastern Pacific Ocean (TEP) is a highly productive marine environment, responsible for around $10 \%$ of global marine productivity (Pennington et al., 2006). This region and adjacent areas contain some of the world's largest fisheries, such as the Peruvian anchoveta fishery (Chavez et al., 2003; Chavez and Messié, 2009). Much of this productivity is driven by seasonal upwelling events that draw nutrient-rich, cooler water to the photic zone (Pennington et al., 2006). Many species of commercially and ecologically important animals rely on the high productivity of these upwellinginfluenced areas, including tunas, dolphinfishes, marlins, turtles, marine mammals, and migratory elasmobranchs (Block et al., 2011; Dewar et al., 2011; Martin et al., 2016; Moteki et al., 2001), although the relative reliance of this high productivity on upwelling periods remains largely unquantified. These organisms in turn have significant conservation, economic, and nutritional value to human populations, including sport and food fisheries, fishmeal, and fish oil production. For example, fishery and aquaculture production in Central America alone generate an average of around 400k tonnes per year, with a mean annual value over 2 billion US dollars (Lauri et al., 2014), accounting for almost $3 \%$ of the economy for this entire region. These values include only small contributions from the Caribbean Sea (e.g. $<1$ \% of vessels in Panama (Lauri et al., 2014)), and the great majority of production occurs in Pacific waters.

Despite the importance of upwelling pelagic ecosystems documented in temperate regions, such systems remain poorly understood in the tropics. In the North Pacific Ocean, apex predator movements have been found to intercept upwelling areas (Block et al., 2011). Of the few studies that have been conducted on upwelling systems, most investigate either the whole ecosystem within one time period (e.g. Bode et al., 2003; Coelho-Souza et al., 2012), or temporal dynamics of one or two ecosystem components (e.g. Bode et al., 1996; Ekau et al., 2018; Madigan et al., 2012), often using one or two sampling points in multiple years rather than repeated sampling throughout a year. Often such studies are also reliant on modelled rather than empirical data to characterise trophic ecology (e.g. Cury et al., 2000; Duarte and García, 2004), and measure population dynamics rather than direct trophic and nutrient flows (e.g. Santos et al., 2007). Few studies have empirically measured and described whole ecosystem nutrient dynamics and the timing of nutrient transfer throughout the year in tropical pelagic ecosystems. Increasing the knowledge in these areas will 
allow more accurate tracking of behavioural, e.g. migration and feeding, and nutrient ecology throughout ecosystems.

Coastal upwelling systems in the TEP are responses to a combination of a deep pool of water with high nutrient concentrations in that region (https://www.nodc.noaa.gov/OC5/woa18/) and a regionally shallow thermocline, 30-50 m deep (Fiedler and Talley, 2006), which facilitates rapid movements of nutrient-rich deeper waters to surface areas. There are three major seasonal upwellings in the TEP, all of them active during the northern hemisphere winter when tradewinds blow across low areas of the central American isthmus and move surface waters offshore: the Gulf of Tehuantepec off southern Mexico, the Gulf of Papagayo off northern Costa Rica and the Gulf of Panama (Fig 1). The Panama upwelling system is the only one that includes a broad area of continental shelf on its inshore side, represented by the shallow ( $\sim 50 \mathrm{~m}$ deep) Bay of Panama, in which our study was based. The Gulf of Panama is an important area of upwelling in the TEP. This ecosystem is highly productive, in large part due to large nutrient input from wind-driven seasonal upwelling (D'Croz and O'Dea, 2007; D'Croz and Robertson, 1997; McCreary et al., 1989; Pennington et al., 2006), and is an important nutrient source within the TEP. There is strong seasonality in this system between the cooler, wet months of the non-upwelling season between May and December with light and variable winds, and the hot, dry months between January and April with strong offshore trade winds, resulting in marked contrasts in temperature and nutrient availability in the pelagic zone. In the non-upwelling season, the relatively still oceanic conditions allow the local surface waters to absorb solar radiation, which increases temperatures, while the strong offshore trade winds of the dry season push the surface waters out to sea, drawing cooler waters up from the deep ocean (D'Croz and O'Dea, 2007; D'Croz and Robertson, 1997; and see McCreary et al., 1989 for the Tehuantepec and Papagayo systems). This upwelling stimulates productivity within the Bay and out into the open Pacific Ocean, carried on the Panama Current (Legeckis, 1988; Samuelsen and O'Brien, 2008; Stuhldreier et al., 2015). Primary productivity, measured as chlorophyll- $\alpha$ (mass of photosynthetic pigment, $\mathrm{Chl}-\alpha$ ), increases up to fivefold in upwelling season compared to the nonupwelling season (D'Croz and O'Dea, 2009, 2007; D'Croz and Robertson, 1997), when the thermocline shoals almost to the surface. This increase in primary production is likely due to a release from the nitrate-limitation during the non-upwelling season, with an order of magnitude increase in dissolved nitrate in surface waters during upwelling season. Outside of the upwelling season, warm, low salinity surface waters originating from high rainfall along the Pacific coast of eastern Panama and, especially, Colombia, can be detected as far as $95^{\circ} \mathrm{W}$, and cool waters from the upwelling detected in a south-westward direction for over $1500 \mathrm{~km}$, as far as the Galapagos 
Islands (Alory et al., 2012; Legeckis, 1988), meaning that production in the waters of the Panama Bay has wide-ranging influence in the TEP.

Figure 1. Examples of (A) weekly sea surface temperature anomaly (11-17.03.2019, blue: colder and orange: warmer than the historical average for 1985-2012; image credit: NOAA) and (B) chlorophyll$\alpha$ concentration (01.01.2004; image credit: SeaWIFS Project) during upwelling, showing major upwelling areas in the Eastern Pacific

The Bay of Panama upwelling system attracts a megafauna that is amongst the most diverse in the Tropical Eastern Pacific area (Lezama-Ochoa et al., 2017), and features a rich variety of fish species (Robertson and Allen, 2015). The increase in primary productivity due to upwelled nutrients concurrently drives high production in resident forage fishes such as the industrially fished Pacific anchoveta, Cetengraulis mysticetus, and Pacific thread herring, Opisthonema spp.. These small fishes show the greatest size-based aggregations for spawning in this area during upwelling season, with more diffuse distribution offshore and in deeper waters out of upwelling times, possibly making them less accessible to predators (Bayliff, 1963; Saetersdal et al., 1999). Around 80 thousand tonnes of these fishes are taken annually, which are important to both the economy of Panama and to the pelagic food web (CeDePesca, 2015; Csirke and Tandstad, 2005; Cury et al., 2000). These smaller fish support commercially important, migratory, upper trophic level predators such as yellowfin tuna, Thunnus albacares, and mahi mahi, Coryphaena hippurus (Block et al., 2011; Lasso et al., 1999; Thompson et al., 2012). Yellowfin tuna are known to spawn offshore in the Panama bight in the nonupwelling season (Wexler et al., 2007), possibly after having built up nutrient reserves from the increased abundance of forage fishes during upwelling. Larval tuna are also thought to be reliant on upwelled production around the TEP and show reduced survival in El Niño years when upwelling is suppressed, although the species shows increased spawning stock recruitment following El Niño events (Lehodey et al., 2006; Pedraza and Díaz Ochoa, 2006).

The stable isotope composition of primary production integrated by successive consumers during upwelling differs from that derived directly from atmospheric sources, and therefore provides a natural marker for upwelling-derived nutrients throughout the trophic web (Argüelles et al., 2012; Minami and Ogi, 1997). Upwelled waters carry higher levels of nutrients than non-upwelled waters, and these nutrients generally have higher $\delta^{15} \mathrm{~N}$ and $\delta^{13} \mathrm{C}$ values due to a combination of different environmental conditions during fixation by phytoplankton and isotopic alteration associated with 
remineralisation of sinking and settling particulate organic matter at depth. The $\mathrm{C}$ and $\mathrm{N}$ stable isotopic composition of primary production in upwelling regions is therefore significantly different to that of non-upwelling regions (Altabet et al., 1999; Graham et al., 2010; Libes and Deuser, 1988; Wu et al., 1999). These isotopic differences in dissolved nutrient source are transferred to organic compounds fixed during primary production in surface waters (Goericke and Fry, 1994; Lara et al., 2010) and subsequently transferred up the food web to higher trophic level consumers. Takai et al. (2000) and Argüelles et al. (2012) found that squid captured close to eastern Pacific upwelling systems were, for example, up to $6 \%$ higher in $\delta^{15} \mathrm{~N}$ and up to $3 \%$ higher in $\delta^{13} \mathrm{C}$ values than those sampled from non-upwelling regions. The seasonality of the pelagic ecosystem in the Bay of Panama, with its strong contrasts between a cooler, nutrient-rich upwelling period and warmer, nutrient-poor conditions during non-upwelling (rainy) periods is likely to be expressed in the stable isotope composition of animals feeding in the area.

The carbon isotope composition of pelagic bulk primary production is strongly related to the isotope composition of the basal carbon source, such as upwelled dissolved inorganic carbon, and to the temperature of the seawater in which it grows (Magozzi et al., 2017; Tagliabue and Bopp, 2008). The relationship between carbon isotope composition and temperature is due to factors such as growth rate, cell geometry, and amount of available dissolved inorganic carbon (Lara et al., 2010; Tagliabue and Bopp, 2008). Upwelled waters are cooler, with more dissolved inorganic carbon due to respiration, which often originates from sources that have been remineralised by the actions of bacteria at depth (Cavan et al., 2017). The predictable relationship between temperature and carbon isotope composition of basal production means that changes in sea surface temperature due to upwelling should alter the isotopic composition of primary production, and subsequently of animals feeding within the ecosystem reliant on this primary production. In this way, upwelling-derived nutrient use can be detected within higher trophic levels of the pelagic ecosystem (Lopez-Lopez et al., 2017; Thompson et al., 2012). To detect upwelling signals, however, it is first important to have information on the baseline, without the influence of upwelling.

157 Our understanding of tropical inshore upwelling ecosystems, such as that typified by the Bay of Panama, is hindered by a lack of quantitative ecological measurements on nutrient sources, nutrient transfer between trophic levels, and measurements of trophic level spacing, particularly in the pelagic zone. Pelagic animals, however, are the customary targets of both commercial and recreational fisheries. For example, the most abundant and exploited fish in the world, the Peruvian anchoveta, is a pelagic consumer reliant on upwelled nutrients in the temperate eastern Pacific off Peru (Cury et al., 2000; Cushing, 1971). To understand the ecology of an ecosystem, it is necessary to understand the flow of nutrients through the trophic positions of the food web. Stable isotope 
analysis is a relatively recently developed tool that has become useful for determining ecosystemlevel patterns in size-based structure and movement of energy between trophic levels (Blanchard et al., 2017; Reum et al., 2019).

In this study, we aim to determine the spatio-temporal patterns in variability of carbon and nitrogen stable isotope composition throughout the pelagic ecosystem of the Bay of Panama in upwelling and non-upwelling conditions, and how these patterns are recorded in organisms throughout the ecosystem from primary producers to apex predators. We present the baseline stable isotope variability in a tropical pelagic ecosystem in a time of relatively stable environmental conditions, outside of the influence of upwelling. We subsequently determine the relative enrichment of stable isotopes from this baseline between each trophic step and give a clear picture of the pelagic ecosystem structure, including measures of predator-prey mass ratio. We use a monthly time series of the stable isotope composition of resident fish species in conjunction with environmental data to analyse the timing and duration of nutrient transfer and integration from the baseline into the consumers within this ecosystem. The information we present here can be used to determine trophic behaviour and movement patterns in animals using this area, and to assess ecosystem-scale response times to the influences of climate change, alterations in fishing pressures, and El Niño events.

Materials \& methods

\subsection{Sample collection}

Samples were collected throughout the pelagic ecosystem of the Bay of Panama, out to a distance of $\sim 120 \mathrm{~km}$ from the Panama Canal.

Pelagic particulate organic matter (POM) samples were taken on a relatively regularly-spaced grid across the Gulf of Panama to $120 \mathrm{~km}$ from the Smithsonian Tropical Research Institute's marine station at Isla Naos, between September and early December 2014, to determine variability in the isotopic baseline of carbon and nitrogen stable isotope compositions outside of the wind-driven upwelling season (Bode et al., 2003; O’Reilly et al., 2002; Vokhshoori et al., 2014). The isotopic composition of plankton during this period should be representative of the prevailing environmental and taxonomic conditions in the Gulf in non-upwelling season. These samples were taken by horizontal tow at $\sim 10 \mathrm{~m}$ below the surface for 10 minutes using a straight conical SEA GEAR plankton net with $125 \mu \mathrm{m}$ mesh, towed behind a motorised boat at $\sim 9 \mathrm{~km} \mathrm{hr}^{-1}$. The samples were rinsed from the cod-end into a labelled plastic container and immediately fixed with ethanol. In the laboratory, 
samples were subsequently filtered through a $200 \mu \mathrm{m}$ sieve to divide the sample into larger plankton $>200 \mu \mathrm{m}$, for ease of reference subsequently denoted zooplankton (ZP), from which visible detritus (e.g. plastics, plant matter) and macroplankton (medusas, siphonophores and salps) were removed, and smaller plankton $<200 \mu \mathrm{m}$, subsequently denoted phytoplankton (PP) (Moloney and Field, 1991), from which visible zooplankton and detritus were removed. POM samples were taken throughout the Bay of Panama (Fig. 2) from September to December 2014.

All non-POM sampling was opportunistic. Bulk gelatinous zooplankton (scyphomedusae and salpidae) were sampled between the surface and c. $10 \mathrm{~m}$ using a $3 \mathrm{~mm}$ mesh landing net. Benthic predatory reef fishes Pacific graysby Cephalopholis panamensis, starry grouper Epinephelus labriformis, and pelagic planktivorous fish rainbow chub Kyphosus ocyurus were taken by spearfishing. The benthic reef fishes were collected opportunistically and included within these analyses to determine the connectivity of reef systems to pelagic production in the Bay. Benthopelagic planktivorous fish Pacific anchoveta Cetengraulis mysticetus and benthic predatory fish tallfin croaker Micropogonias altipinnis were subsampled from a commercial seine catch taken by ProMarina S.A. for fish meal and oil. Finally, pelagic predatory fishes mahi mahi Coryphaena hippurus, sierra mackerel Scomberomorus sierra, and yellowfin tuna Thunnus albacares were sampled from the Mercado de Mariscos (Seafood Market) in Panama City for the reliability of obtaining samples from these pelagic species; these predatory species were not always available, or very few animals were for sale during market sampling, resulting in low sample sizes. Rainbow chub Kyphosus ocyurus is a resident, zooplanktivorous pelagic fish (Knudsen and Clements, 2013) that was sampled for carbon and nitrogen stable isotope composition at least once per month from April 2014 to January 2015, inclusive, from locations near Islas Saboga and Pachequilla, within $4 \mathrm{~km}$ of one another in Las Perlas archipelago. This period incorporated both upwelling and non-upwelling months. All samples were immediately stored chilled in an insulated box with freezer packs for transport, then frozen at $-20^{\circ} \mathrm{C}$ within one to three hours of collection. Fish total length, jellyfish diameter, salp length $(\mathrm{cm})$, and location of capture were recorded at point of collection, along with depth; whole wet mass of gelatinous plankton and fishes (g) were measured and recorded before laboratory dissection.

Gelatinous plankton (jellyfish and salp) were dissected to remove all organs, leaving only the bell of the jellyfish and the tunic of the salp, which were thoroughly and repeatedly washed in Millipore water prior to dissection for isotope analysis (MacKenzie et al., 2017). pump onto pre-combusted Whatman glass fibre filters. These plankton samples were acidified by 
fuming with $1 \mathrm{M} \mathrm{HCl}$ for 24 hours in a glass desiccation chamber to remove inorganic carbonates.

231 Samples of dorsal white muscle were dissected from the fishes and cleaned repeatedly and thoroughly in Millipore water. Filters, fish muscle, invertebrate, and plankton samples were dried to a constant mass for $24-48$ hours in a $60^{\circ} \mathrm{C}$ oven. All samples were then ground to fine, homogenous powder with a pestle and mortar or automated ball mill for stable isotope analysis.

\begin{tabular}{|c|c|c|c|c|c|c|}
\hline Sample/species name & $\begin{array}{l}\text { Date(s) of } \\
\text { sampling }\end{array}$ & Season & $\mathrm{N}$ & Size & Category & $\begin{array}{l}\text { Resident/ } \\
\text { migrant }\end{array}$ \\
\hline $\begin{array}{l}\text { Phytoplankton } \\
(\mathrm{n}=36)\end{array}$ & $\begin{array}{l}24.09 .2014 \\
10.10 .2014 \\
14.10 .2014 \\
16.10 .2014 \\
30.10 .2014 \\
31.10 .2014 \\
27.11 .2014 \\
04.12 .2014 \\
10.12 .2014\end{array}$ & Non-upwelling & $\begin{array}{l}4 \\
4 \\
1 \\
1 \\
5 \\
8 \\
1 \\
1 \\
11\end{array}$ & $<200 \mu \mathrm{m}$ & $\begin{array}{l}\text { Primary } \\
\text { production (PP) }\end{array}$ & Resident \\
\hline $\begin{array}{l}\text { Zooplankton } \\
(n=75)\end{array}$ & $\begin{array}{l}24.09 .2014 \\
10.10 .2014 \\
14.10 .2014 \\
16.10 .2014 \\
30.10 .2014 \\
31.10 .2014 \\
27.11 .2014 \\
04.12 .2014 \\
10.12 .2014\end{array}$ & Non-upwelling & $\begin{array}{l}10 \\
7 \\
9 \\
8 \\
8 \\
10 \\
11 \\
1 \\
11\end{array}$ & $\geq 200 \mu \mathrm{m}$ & Zooplankton (ZP) & Resident \\
\hline Salp $(n=1)$ & 13.03 .2014 & Upwelling & 1 & NA & ZP (Salp) & Resident \\
\hline $\begin{array}{l}\text { Scyphozoa (Aurelia sp., } \\
\text { Chrysaora fuscescens, } \\
\text { unid. Scyphozoan) (n=3) }\end{array}$ & $\begin{array}{l}03.03 .2014 \\
09.06 .2014 \\
02.10 .2014 \\
\end{array}$ & $\begin{array}{l}\text { Upwelling } \\
\text { Non-upwelling } \\
\text { Non-upwelling } \\
\end{array}$ & $\begin{array}{l}1 \\
1 \\
1 \\
\end{array}$ & $\begin{array}{l}\text { NA } \\
116.5 \mathrm{~g} \\
\mathrm{NA}\end{array}$ & $\begin{array}{l}\text { ZP / planktivore } \\
\text { (Jelly) }\end{array}$ & Resident \\
\hline $\begin{array}{l}\text { Pacific anchoveta } \\
\text { Cetengraulis mysticetus } \\
(\mathrm{n}=72)\end{array}$ & $\begin{array}{l}03.04 .2014 \\
23.05 .2014\end{array}$ & $\begin{array}{l}\text { Upwelling } \\
\text { Non-upwelling }\end{array}$ & $\begin{array}{l}52 \\
20\end{array}$ & $\begin{array}{l}37.1 \mathrm{~g} \\
\text { (mean) } \\
\pm 17.7 \\
\text { (sd) }\end{array}$ & $\begin{array}{l}\text { Benthopelagic } \\
\text { planktivore }\end{array}$ & Resident \\
\hline $\begin{array}{l}\text { Rainbow chub } \\
\text { Kyphosus ocyurus } \\
(\mathrm{n}=37)\end{array}$ & $\begin{array}{l}09.04 .2014 \\
06.05 .2014 \\
09.06 .2014 \\
03.07 .2014 \\
04.08 .2014 \\
02.09 .2014 \\
02.10 .2014 \\
30.10 .2014 \\
28.11 .2014 \\
29.12 .2014 \\
27.01 .2014 \\
\end{array}$ & $\begin{array}{l}\text { Upwelling } \\
\text { Non-upwelling } \\
\text { Non-upwelling } \\
\text { Non-upwelling } \\
\text { Non-upwelling } \\
\text { Non-upwelling } \\
\text { Non-upwelling } \\
\text { Non-upwelling } \\
\text { Non-upwelling } \\
\text { Upwelling } \\
\text { Upwelling }\end{array}$ & $\begin{array}{l}5 \\
5 \\
3 \\
3 \\
3 \\
3 \\
3 \\
3 \\
3 \\
3 \\
3\end{array}$ & $\begin{array}{l}422.5 \mathrm{~g} \\
\text { (mean) } \\
\pm 181.5 \\
(\mathrm{sd})\end{array}$ & $\begin{array}{l}\text { Pelagic } \\
\text { planktivore }\end{array}$ & Resident \\
\hline $\begin{array}{l}\text { Pacific graysby } \\
\text { Cephalopholis } \\
\text { panamensis }\end{array}$ & 11.03 .2014 & Upwelling & 3 & $\begin{array}{l}258.3 \mathrm{~g} \\
\text { (mean) } \\
\pm 45.4 \\
\text { (sd) }\end{array}$ & Benthic predator & Resident \\
\hline $\begin{array}{l}\text { Starry grouper } \\
\text { Epinephelus labriformis }\end{array}$ & 11.03 .2014 & Upwelling & 4 & $\begin{array}{l}287.5 \mathrm{~g} \\
\text { (mean) } \\
\pm 85.4\end{array}$ & Benthic predator & Resident \\
\hline
\end{tabular}




\begin{tabular}{|c|c|c|c|c|c|c|}
\hline & & & & (sd) & & \\
\hline $\begin{array}{l}\text { Tallfin croaker } \\
\text { Micropogonias altipinnis }\end{array}$ & 03.04 .2014 & Upwelling & 1 & $875 \mathrm{~g}$ & Benthic predator & \\
\hline $\begin{array}{l}\text { Mahi mahi } \\
\text { Coryphaena hippurus } \\
(\mathrm{n}=6)\end{array}$ & $\begin{array}{l}21.03 .2014 \\
06.06 .2014 \\
22.10 .2014 \\
\end{array}$ & $\begin{array}{l}\text { NA-open } \\
\text { Pacific Ocean } \\
\text { Non-upwelling } \\
\text { Non-upwelling }\end{array}$ & $\begin{array}{l}3 \\
2 \\
\end{array}$ & $\begin{array}{l}2448.6 \mathrm{~g} \\
\text { (mean) } \\
\pm 315.5 \\
\text { (sd) }\end{array}$ & Pelagic predator & Migrant \\
\hline $\begin{array}{l}\text { Sierra mackerel } \\
\text { Scomberomorus sierra } \\
(n=14)\end{array}$ & $\begin{array}{l}23.03 .2014 \\
06.06 .2014 \\
22.10 .2014 \\
26.02 .2014 \\
\end{array}$ & $\begin{array}{l}\text { Upwelling } \\
\text { Non-upwelling } \\
\text { Non-upwelling } \\
\text { Upwelling }\end{array}$ & $\begin{array}{l}5 \\
4 \\
3 \\
2 \\
\end{array}$ & $\begin{array}{l}1461.0 \mathrm{~g} \\
\text { (mean) } \\
\pm 1045.4 \\
(\mathrm{sd})\end{array}$ & Pelagic predator & Resident \\
\hline $\begin{array}{l}\text { Yellowfin tuna } \\
\text { Thunnus albacares } \\
(\mathrm{n}=4)\end{array}$ & $\begin{array}{l}21.03 .2014 \\
06.06 .2014 \\
22.10 .2014 \\
26.02 .2015\end{array}$ & $\begin{array}{l}\text { NA - Chiriquí } \\
\text { Non-upwelling } \\
\text { Non-upwelling } \\
\text { Upwelling + } \\
\text { Chiriquí }\end{array}$ & $\begin{array}{l}1 \\
2 \\
1 \\
2\end{array}$ & $\begin{array}{l}5067.6 \mathrm{~g} \\
\text { (mean) } \\
\pm 2828.4 \\
(\mathrm{sd})\end{array}$ & Pelagic predator & Migrant \\
\hline
\end{tabular}

Table 1. Details of all collected samples. Categories are defined as follows: Primary production (PP) is the bulk plankton size fraction $<200 \mu \mathrm{m}$, treated as pelagic phytoplankton; zooplankton (ZP) is the bulk plankton size fraction $>200 \mu \mathrm{m}$, treated as pelagic zooplankton; benthopelagic planktivores are fishes feeding on plankton from both benthic and pelagic sources; pelagic planktivores are fishes feeding on pelagic plankton; benthic predators are demersal fishes taking prey items from benthic habitats; and pelagic predators are pelagic fishes whose prey is other pelagic fishes.

\subsection{Organism ecology}

Phytoplankton are subject to seasonal blooms due to increased nutrient availability from thermocline shoaling almost to surface waters during the upwelling season, when a fivefold increase in Chl- $\alpha$ has been observed within the Bay of Panama ( $D^{\prime} \mathrm{Croz}$ and $\left.\mathrm{O}^{\prime} \mathrm{Dea}, 2007\right)$. The isotopic compositions of these baseline organisms reflect a combination of taxonomy, the environmental conditions in which they grow, e.g. temperature, and the isotopic composition of the nitrogen and carbon nutrient sources that they integrate (Lara et al., 2010; Montoya, 2008; Tagliabue and Bopp, 2008)

Zooplankton respond to the increased grazing availability of phytoplankton with a concurrent seasonal bloom pattern. This category of animals is considered largely herbivorous within this ecosystem (Marra et al., 1987)

Gelatinous zooplankton, here salps and jellyfishes (medusae) are pelagic macrozooplankton, that feed by filtering small planktonic organisms from the water (salps and jellyfish), and by capturing small pelagic animals in their tentacles. Due to this generalist feeding mode, potentially spanning multiple trophic positions, trophic level assignment is not given for these organisms, although salps are largely herbivorous and medusae are largely carnivorous (Kruse et al., 2015; Molina-Ramírez et 
al., 2015). These animals are, similar to smaller plankton, known to produce blooms during upwelling season (Miglietta et al., 2008).

Planktivores

261

262

The Pacific anchoveta Cetengraulis mysticetus is a benthopelagic fish that feeds on plankton by filtering water through its gill rakers. Unusually for anchovy-type filter feeders, C. mysticetus actively consumes both pelagic and benthic plankton, particularly benthic diatoms in adult fish. This species has a specialised muscular gizzard-like stomach for crushing hard-shelled diatoms to render the contents accessible, and appears to feed more benthically with increasing age/size (Bayliff, 1963). It might be speculated that the large schools aggregating in shallow waters could stir up the benthic surface layer, allowing access to filter benthic diatoms using their gill rakers, but further investigation would be necessary to determine whether this is the case. This fish appears to be largely phytoplanktivorous, based on Bayliff's (1963) stomach contents analyses.

Rainbow chub Kyphosus ocyurus is another tropical planktivore, although this species is largely zooplanktivorous and epipelagic-feeding (Dominici-Arosemena and Wolff, 2006; Robertson and Allen, 2015). This species is often associated with rocky shores and offshore reefs, and a widespread resident in the study area throughout the year.

Benthic predators

The Pacific graysby Cephalopholis panamensis and starry grouper Epinephelus labriformis are reefassociated benthic-feeding carnivorous fishes, with a diet comprising small fishes and invertebrates (Craig et al., 1999; Dominici-Arosemena and Wolff, 2006). These fishes are considered resident throughout the year within the study area. Tallfin croaker Micropogonias altipinnis is another benthic fish, although with a broader habitat range covering sandy, muddy, and estuarine areas. These fish are carnivorous, with prey including fishes and benthic invertebrates (Fischer et al., 1995), and considered resident within the study area.

Pelagic predators

Mahi mahi Coryphaena hippurus is an epipelagic, circumtropical and sub-tropical predator, consuming fishes, squid, and crustacea (Tripp-Valdez et al., 2010; Varela et al., 2017). These fishes are highly itinerant, and found mainly in the study area during December to April (Lasso et al., 1999), coinciding with upwelling season. Sierra mackerel Scomberomorus sierra is another epipelagic, predatory fish, preying largely on smaller fishes such as anchovies (Collette and Nauen, 1983). This species is believed to have strong population structure, with localised genotypes linked to spawning area proximity (Domínguez López et al., 2010), thus is considered resident in the study area. 
Yellowfin tuna Thunnus albacares is, like mahi mahi, a migratory circumtropical and sub-tropical predator, also feeding on fishes, crustacea and squid (Olson and Boggs, 1986). These fish are considered migrants to the study area.

\section{Seasonality and environmental data}

Mean monthly SST values were calculated from sea surface temperature measurements at STRI's Isla Pacheca monitoring station (lat. 8.662, lon. -79.054, https://biogeodb.stri.si.edu/physical_monitoring/research/sst). Data here have been recorded at 30minute intervals continuously since 1995 using Onset Hobo temperature loggers, at a depth of $6 \mathrm{~m}$ below the surface. This station in Las Perlas is within $3 \mathrm{~km}$ of the capture locations for the time series of $K$. ocyurus samples. Monthly data were calculated as means of all recorded SST data within each month from November 2013 to February 2015. From these Isla Pacheca data, the SST values from May - December within each year were between 27.8 and $28.8^{\circ} \mathrm{C}$, while values from January - April 2014 and January - February 2015 were lower, between 22.4 and $26.3^{\circ} \mathrm{C}$. As upwelled waters are cooler than surface waters (Lehodey, 2001) and SST better reflects the conditions directly experienced within the marine ecosystem than measures of wind stress, SST values were used to temporally define upwelling and non-upwelling seasons. The months of January to April are therefore considered to be the upwelling period.

To test for spatially resolved anthropogenic and open oceanic contributions to the stable isotope composition of plankton in the Bay of Panama, shortest linear distances were measured to the nearest 100 m using Google Maps tools (@2018 Google Imagery, TerraMetrics) between plankton sample locations and:

- the closest shore,

- $\quad$ the closest settlement,

- $\quad$ the closest area of mainland Panama,

- Panama Canal (taken as a point in the centre of the Canal, next to the Bridge of the Americas, and used as a proxy for distance from the influence of Panama City),

- the open Pacific Ocean (taken as a point in the centre of the entrance to the Bay of Panama, on the continental shelf at approximately $10 \mathrm{~km}$ from the continental slope),

Bathymetry data were obtained from the ETOPO1 dataset (Amante and Eakins, 2009) hosted on the NOAA server, using the 'marmap' package in R (Pante and Simon-Bouhet, 2013). 
321 High resolution chlorophyll- $\alpha$ concentration data at the surface of the ocean ( $0 \mathrm{~m}$ altitude) were obtained from MODIS/Aqua dataset (http://coastwatch.pfeg.noaa.gov/erddap/tabledap/erdMBchla8day LonPM180.html) on a 0.025 degree latitude-longitude resolution; full acknowledgements to the NOAA CoastWatch Program and NASA's Goddard Space Flight Center, and OceanColor Web (Fu et al., 1998; Gordon and Wang, 1994; O'Reilly et al., 2000; Shettle and Fenn, 1979).

\subsection{Stable isotope analysis}

Samples were analysed for carbon and nitrogen stable isotope composition using a Flash-HT elemental analyser coupled to a Thermo Scientific Delta V Advantage isotope ratio mass spectrometer (EA-IRMS) in the Smithsonian Tropical Research Institute Stable Isotope Laboratory. Samples were run concurrently with the following in-house standards of known isotope composition: ammonium sulfate, NIST peach leaves, aspartic acid, STRI-sugar B, STRI-C3, and, sucrose; and with international standards IAEA-N1 and IAEA-N2, IAEA-polyethylene with precision of 0.4 and $0.1 \%$ ( $\pm \mathrm{SD}$ ) for $\delta^{13} \mathrm{C}$ and $\delta^{15} \mathrm{~N}$, respectively.

\subsection{Data analysis}

All statistical analyses were run using R software version 3.4.3 (R Development Core Team, 2011).

Lipid correction

For animals (excluding salps which have a carbohydrate tunic), $\delta^{13} \mathrm{C}$ values were arithmetically corrected for lipid content to allow comparability with other values if atomic C:N ratio was $\geq 4.0$, otherwise measured values were used. Lipid correction was carried out according to the final revised equation from Kiljunen et al. (2006). Lipid-corrected $\delta^{13} C$ values are denoted $\delta^{13} C^{\prime}$ hereafter. Phytoplankton $\delta^{13} \mathrm{C}$ values were not corrected as it is not possible to separate cellulose from lipid content through atomic C:N ratios. Excluding phytoplankton samples, $46 \%$ of the samples required lipid correction. Post-correction, there was no significant relationship between $\delta^{13} \mathrm{C}^{\prime}$ values and C:N ratios.

\section{Mass correction}


To remove the effect of mass on $\delta^{15} \mathrm{~N}$ values and make the animals directly comparable, $\delta^{15} \mathrm{~N}$ values were corrected to a standard mean mass for pelagic predators according to equation 2 :

Where $\delta^{15} \mathrm{~N}^{\prime}$ is the mass-corrected isotope value, $\delta^{15} \mathrm{~N}$ is the original measured value, $\delta^{15} \mathrm{~N}_{\text {calc }}$ denotes the expected isotope value for the body mass of that fish given the regression coefficient of the relationship between mass and $\delta^{15} \mathrm{~N}$ values for the pelagic predator fishes, and $\delta^{15} \mathrm{~N}_{\text {mean }}$ denotes the calculated isotope value for the mean body mass of the pelagic predator fishes.

Mapping

Phytoplankton and zooplankton stable isotope values were mapped using inverse distance weighted interpolation in the R gstat package (Gräler et al., 2016; Pebesma, 2004), where closer values are given higher weighing in interpolation than values measured further away, i.e. a greater likelihood of similarity, as is expected from spatial patterns in stable isotope composition (e.g. Bowen, 2010), see Fig. 2. Maps were created in the R ggplot2 package (Wickham, 2016).

Predator-prey mass ratio (PPMR) calculation

367 Community PPMR $=\log$ base $\frac{\Delta 15 \mathrm{~N}}{\text { slope }}$ between differences in trophic levels or tissue-diet fractionation (TDF) and around the slope of the $\delta^{15} \mathrm{~N}-\log _{2}$ mass relationships.

Nutrient transfer time

To determine the lag time between SST-controlled $\delta^{13} \mathrm{C}$ values in primary production and the integration of that signal, via zooplankton consumption and integration of the primary production, and subsequent consumption and integration of the zooplankton by $K$. ocyurus, mean $\delta^{13} \mathrm{C}$ values measured in K. ocyurus dorsal muscle for every month from April 2014 to January 2015 inclusive were cross-correlated with mean monthly sea surface temperature records from January 2014 to February 2015, calculated from measurements taken at the Isla Pacheca monitoring station, within 3 $\mathrm{km}$ of the $K$. ocyurus sampling sites. 
All data are available in Appendix 1.

Stable isotope values for separated bulk plankton size fractions, denoted phytoplankton $(<200 \mu \mathrm{m})$ and zooplankton (> $200 \mu \mathrm{m}$ ), show the baseline spatial isotopic variability outside of upwelling influence. The range in $\delta^{13} \mathrm{C}\left(\delta^{13} \mathrm{C}^{\prime}\right)$ and $\delta^{15} \mathrm{~N}$ values is very high for both phytoplankton and zooplankton, although higher in $\delta^{15} \mathrm{~N}$ (Table 2). For comparison, the zooplankton isoscapes of Graham et al. (2010) show a total $\delta^{15} \mathrm{~N}$ range of $10 \%$ for the entire Atlantic Ocean. The overall geographic pattern is, however, relatively stable in isotopic composition of both $\mathrm{C}$ and $\mathrm{N}$, as detailed below, with a small number of extreme values driving the large range (Table 2, Fig. 2).

Table 2. Summary statistics of stable isotope values for plankton size fractions; arithmetic lipid correction was applied to the $\delta^{13} \mathrm{C}$ values of the zooplankton fraction.

\begin{tabular}{|l|c|c|c|c|c|c|c|c|c|c|c|}
\hline & \multirow{3}{*}{} & \multicolumn{4}{|c|}{$\delta^{13} \mathrm{C}(\mathrm{PP})$ or $\delta^{13} \mathrm{C}^{\prime}(\mathrm{ZP}) \% \mathrm{c}$} & \multicolumn{5}{c|}{$\delta^{15} \mathrm{~N}$} \\
\cline { 3 - 13 } & $\mathrm{n}$ & $\mathrm{min}$ & $\max$ & mean & range & $\mathrm{SD}$ & min & max & mean & range & $\mathrm{SD}$ \\
\hline Phytoplankton $(<200 \mu \mathrm{m})$ & 36 & -27.4 & -19.5 & -21.2 & 7.9 & 1.4 & -1.5 & 11.4 & 6.2 & 12.9 & 2.9 \\
\hline Zooplankton $(>200 \mu \mathrm{m})$ & 75 & -22.1 & -16.4 & -18.4 & 5.6 & 1.1 & -3.1 & 10.5 & 8.3 & 13.6 & 1.6 \\
\hline
\end{tabular}

Total variability in non-upwelling months

Isoscapes

Figure 2. Bay of Panama isoscape maps of inverse-distance weighted interpolated values of bulk (A) 
405

406

407

408

409

410

411

412

413

414

415

416

417

418

419

420

421

422

423

424

425

426

427

428

429

430

431

432

433

434

435

The spatial patterns in phytoplankton carbon (Fig. 2A) and nitrogen (Fig. 2B) stable isotope compositions are similar, with some depletion in both isotopes measured in the westernmost parts of the Bay of Panama, particularly around Isla Taboguilla (lat. 8.801, lon. $-79.521 ;-27.4 \% \delta^{13} C,-1.2$ $\% \delta^{15} \mathrm{~N}$ ), near Punta Chame (lat. 8.522, lon. $-79.684 ;-22.2 \% \delta^{13} \mathrm{C}, 1.3 \% \delta^{15} \mathrm{~N}$ ), and offshore from Parita Bay (lat. 8.138, lon. $-80.185 ;-23.5 \% \circ \delta^{13} \mathrm{C},-1.5 \%{ }^{15} \mathrm{~N}$ ). More enriched values were measured towards the north and west, particularly offshore from Rio Chepo (lat. 8.773, lon. -78.977; -19.5\%o $\delta^{13} \mathrm{C}, 8.9 \% \delta^{15} \mathrm{~N}$ ). For $\delta^{15} \mathrm{~N}$ only, the highest values are around Punta Chame (lat. 8.637, lon. -79.620; $11.4 \% \delta^{15} \mathrm{~N},-22.6 \% \delta^{13} \mathrm{C}$ ) and c. $20 \mathrm{~km}$ offshore from Panama City (lat. 8.889, lon. -79.357; $9.9 \%$ $\left.\delta^{15} \mathrm{~N},-21.1 \% \delta^{13} \mathrm{C}\right), \delta^{13} \mathrm{C}$ values at these points are around the mean. The spatial compositions were overall relatively homogenous, with $66 \%$ of the phytoplankton $\delta^{13} \mathrm{C}$ values between -22 and $-20 \%$, and $56 \%$ of the $\delta^{15} \mathrm{~N}$ values between 4.5 and $7.5 \%$.

No significant relationships were found by linear regression between the composition of either carbon or nitrogen phytoplankton isotopes and depth or surface $\mathrm{Chl}-\alpha$ concentration, or direct linear distance $(\mathrm{km})$ from: the closest shore, the closest settlement, the mainland, the freshwater-fed Panama Canal, or the open Pacific Ocean.

\section{Zooplankton (> $200 \mu \mathrm{m})$}

The geographic patterns of zooplankton lipid-corrected carbon (Fig. 2C) and nitrogen (Fig. 2D) stable isotope compositions are similar to one another. Unlike in phytoplankton, however, the lowest values of $\delta^{13} C^{\prime}(-22.1,-22.0)$ co-occur, however, with the highest values of $\delta^{15} \mathrm{~N}(10.5,10.4)$ close to Islas Chapera (lat. 8.581, lon. -79.045) and Pacheca (lat. 8.662, lon. -79.053) in Las Perlas. Highest values of $\delta^{13} C^{\prime}$ were found between Las Perlas and Rio Chepo (lat. 8.773 to 8.834, lon. -79.054 to $78.977 ;-16.4$ to $-16.8 \%$ o $\delta^{13} C^{\prime}, 8.8$ to $9.4 \%$ o $\left.\delta^{15} \mathrm{~N}\right)$. The lowest $\delta^{15} \mathrm{~N}$ values were found next to Isla Pacheca (lat. 8.6623, lon. $-79.0535 ;-20.4 \% \circ \delta^{13} C^{\prime},-3.1 \% \circ \delta^{15} \mathrm{~N}$ ), and between Isla Taboga and mainland Panama (lat. 8.842, lon. -79.565; -21.6\%o $\delta^{13} \mathrm{C}^{\prime}, 2.1 \%{ }^{15} \mathrm{~N}$ ) where the $\delta^{13} \mathrm{C}^{\prime}$ value was also low. The zooplankton spatial compositions were more homogenous than in the phytoplankton with $75 \%$ of the $\delta^{13} \mathrm{C}$ values between -19.3 and $-17.3 \%$, and $68 \%$ of the $\delta^{15} \mathrm{~N}$ values between 7.5 and 9.5 $\%$.

There was a detectable positive relationship between zooplankton $\delta^{15} \mathrm{~N}$ values and shortest linear distance from the nearest shore $\left(F=4.921, R^{2}=0.05, p=0.03\right)$, and the nearest settlement $(F=$ $6.855, R^{2}=0.07, p=0.01$ ), although this relationship is driven almost entirely by six depleted 
measurements between 0-10 km from the shore around the northern islands of Las Perlas Archipelago, and between Isla Taboguilla and mainland Panama. There were no significant relationships between $\delta^{15} \mathrm{~N}$ values and depth, or shortest linear distance to the mainland, Panama Canal/City, or the open Pacific Ocean, nor with surface Chl- $\alpha$ concentration. There were no statistically significant relationships found between zooplankton $\delta^{13} \mathrm{C}^{\prime}$ and depth, or direct linear distance $(\mathrm{km})$ from: the closest shore, the mainland, Panama Canal, or the open Pacific Ocean. There is a marginally significant, positive relationship between $\delta^{13} \mathrm{C}^{\prime}$ and shortest linear distance to the closest settlement $\left(F=3.086, R^{2}=0.03, p=0.08\right)$, which, in combination with the positive relationship between settlement proximity and $\delta^{15} \mathrm{~N}$ values, is suggestive of anthropogenic depletion of $\mathrm{C}$ and $\mathrm{N}$ isotope values in zooplankton.

\subsection{Ecosystem structure: trophic spacing}

We collected stable isotope values across four trophic levels (TL) in a tropical pelagic ecosystem. Based on broad diet category, trophic levels are assigned as follows: phytoplankton (primary producers) are at TL1, zooplankton (primary consumers) at TL2, planktivorous fishes (zooplanktivores) at TL3 (Bayliff, 1963; Dominici-Arosemena and Wolff, 2005; Robertson and Allen, 2015), and predators (piscivores) at TL4 (Collette and Nauen, 1983; Craig et al., 1999; DominiciArosemena and Wolff, 2006; Fischer et al., 1995; Olson and Boggs, 1986; Tripp-Valdez et al., 2010; Varela et al., 2017). Statistical comparison of the mean stable isotope values for each trophic level in this data set gives the tissue-diet spacing between each $\mathrm{TL}$, and for the whole ecosystem, with differences tested using Wilcoxon rank sum tests. Separation in stable isotope values for each TL are reported in Table 3 and shown in Fig. 3.

Table 3. Mean differences \pm SD, and $p$-values (Wilcoxon rank sum test) for $\delta^{15} \mathrm{~N}$ and lipid-corrected $\delta^{13} C^{\prime}$ between trophic levels in the Bay of Panama pelagic ecosystem (note: benthic predators and gelatinous zooplankton were excluded from this analysis due to unclear assignment of trophic position, as were fishes with a reported capture location elsewhere than the Gulf of Panama).

\begin{tabular}{|c|r|c|c|r|c|c|}
\hline & \multicolumn{3}{|c|}{$\Delta^{15} \mathrm{~N}$} & \multicolumn{3}{c|}{$\Delta^{13} \mathrm{C}^{\prime}$} \\
\cline { 2 - 7 } & mean & \pm SD & $\mathrm{p}$ & mean & \pm SD & $p$ \\
\hline TL1 - TL2 & 2.1 & 0.12 & $<\mathbf{0 . 0 0 1}$ & 2.9 & 0.03 & $<0.001$ \\
\hline TL2 - TL3 & 4.3 & 0.01 & $<0.001$ & 2.2 & 0.02 & $<0.001$ \\
\hline
\end{tabular}


463

464

465

466

467

468

469

470

471

472

473

474

475

476

477

478

479

480

481

482

483

484

485

486

487

488

489

490

491

\begin{tabular}{|l|r|r|r|r|r|r|}
\hline TL3 - TL4 & 2.3 & 0.01 & $<0.001$ & 0.1 & 0.01 & 0.9 \\
\hline All & 2.9 & 0.09 & $<0.001$ & 1.7 & 0.08 & $<0.001$ \\
\hline
\end{tabular}

Figure 3. Carbon (lipid-corrected for C:N elemental ratio $\geq 3.9 \%$ for all organisms except phytoplankton and salps) and nitrogen stable isotope data of Bay of Panama organisms; colour denotes species, with ellipses showing $95 \%$ confidence interval values for each species with sufficient data points, and point shape denotes organism category (see also Table 1); dashed lines show mean $\delta^{15} \mathrm{~N}$ values for each approximate trophic level (TL) 1-4 from low to high on the $y$-axis.

All fishes that could be categorised as potentially feeding on prey that included or was comprised entirely of benthic nutrient sources (Cetengraulis mysticetus, Cephalopholis panamensis, Epinephelus labriformis, and Micropogonias altipinnis) had relatively elevated $\delta^{13} C^{\prime}$ values compared with other fishes of similar trophic level with strictly pelagic diets, with the exception of one $C$. panamensis, which was similar in both $\delta^{13} \mathrm{C}^{\prime}$ and $\delta^{15} \mathrm{~N}$ values to pelagic predators, and therefore may have a diet of anomalously pelagic nutrient sources.

\section{Tissue-diet fractionation}

The isotopic spacing, or putative tissue-diet fractionation (TDF, $\Delta$ ) between phytoplankton and zooplankton is 2.1 in $\Delta^{15} \mathrm{~N}$ and 2.9 in $\Delta^{13} \mathrm{C}^{\prime}$ (zooplankton fraction subject to lipid-correction, see Tables 2 \& 3).

K. ocyurus mean $\delta^{13} \mathrm{C}$ value in October 2014 to January 2015 was $-17.6 \%$, while the zooplankton mean value in September to December was -18.4 \%, giving an average tissue-diet spacing of $0.8 \%$ between rainbow chub and zooplankton. For $\delta^{15} \mathrm{~N}$ values, the $K$. ocyurus mean was $13 \%$, while the zooplankton mean was $8.3 \%$, giving a contemporaneous tissue-diet fractionation of 4.7 \%o from pelagic planktivorous fish to zooplankton. C. mysticetus had slightly enriched $\delta^{13} C^{\prime}$ values relative to K. ocyurus sampled during the same time period (April-May 2014), with respective means of -16.4 and $-16.8 \%$. Values of $\delta^{15} \mathrm{~N}$ were, however, very similar at $12.5 \%$ for $C$. mysticetus and $12.7 \%$ for K. ocyurus. Combined K. ocyurus and C. mysticetus give tissue-diet fractionation values of 1.8 to 4.6 $\%$ in $\delta^{13} \mathrm{C}^{\prime}$, and 4.3 to $6.4 \%$ in $\delta^{15} \mathrm{~N}$ from all planktivorous fish to zooplankton and phytoplankton (see Table 2 for mean values). 
The TDF between planktivorous and pelagic predatory fishes is $2.3 \% \circ \Delta^{15} \mathrm{~N}$ and $0.1 \% \circ \Delta^{13} \mathrm{C}^{\prime}$ (see Table 4). For only non-migratory pelagic fishes within the Bay of Panama, these differences are 2.7 $\% \Delta^{15} \mathrm{~N}$ and $0.5 \%$ o $\Delta^{13} \mathrm{C}^{\prime}$.

Overall, the mean TDF for this ecosystem is $2.9 \% \circ \Delta^{15} \mathrm{~N}$ and $1.7 \%{ }^{13} \mathrm{C}^{\prime}$. Using this value of $2.9 \%$ o to calculate trophic level based on the total range in $\delta^{15} \mathrm{~N}$ values, starting with the lowest phytoplankton $\delta^{15} \mathrm{~N}$ value of $-1.5 \%$ at TL1, the maximum calculated trophic level in this ecosystem is 6.2, based on the maximum $\delta^{15} \mathrm{~N}$ value measured from an animal (S. sierra) within the Gulf of Panama (see Appendix for full data).

These data provide values for isotopic offsets that may be used to determine the baseline values and trophic behaviour within this food web throughout the year.

\subsection{Predator-prey mass ratio (PPMR) and ecosystem structure}

The predator-prey mass ratio (PPMR) for all animals with recorded mass sampled in the Bay of Panama ecosystem was $375: 1$, based on measured $\delta^{15} \mathrm{~N}$ values against $\log _{2}$ mass and calculated using equation 1 , using the mean value of $\Delta^{15} \mathrm{~N}$ between trophic levels for the whole ecosystem (Fig. 4a). By excluding non-fishes from the analysis and thereby changing the value of $\Delta^{15} \mathrm{~N}$, this value drops to 113:1. Excluding migratory fishes (mahi mahi, $n=3$, and yellowfin tuna, $n=4$ ), possibly importing $\delta^{15} \mathrm{~N}$ values from areas outside of the Bay of Panama, however, changes both the $\Delta^{15} \mathrm{~N}$ and the slope of the relationship between $\delta^{15} \mathrm{~N}$ and mass, thereby increasing the PPMR to $376: 1$ (Fig. 4b), an almost identical value to that calculated for the whole ecosystem.

$\mathrm{PPMR}_{\text {all }}=2^{\frac{2.9 \pm 0.01}{0.34 \pm 0.03}}=375: 1$ (range: $\left.233-657\right)$

$\mathrm{PPMR}_{\text {allfishes }}=2^{\frac{2.3 \pm 0.01}{0.34 \pm 0.03}}=113: 1$ (range: $77-178$ )

$\mathrm{PPMR}_{\text {residentfishes }}=2^{\frac{2.7 \pm 0.18}{0.32 \pm 0.04}}=376: 1$ (range: $253-1272$ ) 
Table 4. Summary statistics of stable isotope values for fishes by broad functional group.

\begin{tabular}{|l|r|r|c|r|c|}
\hline & \multirow{2}{*}{} & \multicolumn{2}{|c|}{$\delta^{13} \mathrm{C}^{\prime}$} & \multicolumn{2}{c|}{$\delta^{15} \mathrm{~N}$} \\
\cline { 3 - 6 } & $\mathrm{n}$ & mean & $\mathrm{SD}$ & mean & $\mathrm{SD}$ \\
\hline Pelagic planktivores & 37 & -17.5 & 0.54 & 12.7 & 0.42 \\
\hline Benthopelagic planktivores & 72 & -15.8 & 1.42 & 12.5 & 0.50 \\
\hline Pelagic predators & 31 & -16.0 & 0.90 & 14.9 & 0.92 \\
\hline Benthic predators & 8 & -14.6 & 0.65 & 14.3 & 0.64 \\
\hline
\end{tabular}

Temporal trends and mean values of $K$. ocyurus.

Rainbow chub average $\delta^{13} \mathrm{C}$ values were highest in April and May 2014 (April: $-16.9 \% \pm 0.38 \mathrm{sd}, \mathrm{n}=$ 4; May: $-16.6 \% \pm 0.14 \mathrm{sd}, \mathrm{n}=5)$, and lowest in June $2014(-18.1 \% \circ \pm 0.18 \mathrm{sd}, \mathrm{n}=3)$, although the total range was $2.1 \%$, (Figs. $3 \& 5$ ). Average values of $\delta^{13} \mathrm{C}$ showed cyclicity (Fig. $5 \mathrm{~b}$ ), with highest values in April to May 2014, immediately after the December to April upwelling season, lowest values in June 2014, and steady increase from the low in June towards higher upwelling season values (Table 2 and Fig. 5). There was noticeable variation in the composition of both isotopes throughout the 11-month period, however there was no significant correlation between $\delta^{13} \mathrm{C}$ and $\delta^{15} \mathrm{~N}$ values. Overall, the $\mathrm{C}$ and $\mathrm{N}$ isotope values of rainbow chub appear to be higher during and after the upwelling season and lower through the dry season.

Figure 5. (A) Rainbow chub $\delta^{13} \mathrm{C}$ values (black filled circles) and Isla Pacheca mean monthly sea surface temperature values (black line); and (B) cross-correlation at different lag times between rainbow chub $\delta^{13} \mathrm{C}$ values and mean monthly SST at Isla Pacheca, within $3 \mathrm{~km}$ of where the chub were sampled (lat. 8.662, lon. -79.054), each line is one month of lag time from SST to mean $\delta^{13} \mathrm{C}$ value, dashed line indicates significance threshold $(p=0.05)$. 
543 A significant negative correlation was found between monthly rainbow chub $\delta^{13} \mathrm{C}$ values and mean monthly sea surface temperature within $3 \mathrm{~km}$ of capture location, with a lag time of one to two months (one month: $F=43.04, R^{2}=0.56, p<0.001$; two months: $F=19.58, R^{2}=0.36, p<0.001$ ) (Fig. 5b). As rainbow chub are largely zooplanktivores, feeding around trophic level (TL) 3 , this suggests a trophic transfer time for carbon of 0.5 to 1.0 month per TL in this pelagic ecosystem.

There was no significant correlation between rainbow chub $\delta^{15} \mathrm{~N}$ values and SST, neither before nor after correction of the isotope values to $K$. ocyurus mean mass to remove the relationship between size and ${ }^{15} \mathrm{~N}$ composition. A longer time series would be needed to robustly test whether there is a temporal pattern in $\delta^{15} \mathrm{~N}$ values related to upwelling.

\subsection{Isotope patterns in predatory fishes}

Of the three species of pelagic predatory fishes, $C$. hippurus and T. albacares did not differ from one another in lipid-corrected $\delta^{13} C^{\prime}$ values across all sampled areas (Bay of Panama, Gulf of Chiriquí, and open Pacific Ocean), nor did S. sierra T. albacares. We did find that $C$. hippurus values were significantly different from those of $S$. sierra (Wilcoxon sum rank test: $W=2, p<0.005$ ); however caution is advised on this result as only $n=4 C$. hippurus were sampled.

Similar patterns were found in mass-corrected $\delta^{15} \mathrm{~N}^{\prime}$ values to those found in $\delta^{13} \mathrm{C}^{\prime}$ values: significant differences were only found between $C$. hippurus and $S$. sierra (Wilcoxon sum rank test: $W=0, p<$ 0.001 ), although there is some suggestion of a difference between S. sierra and T. albacares at $90 \%$ significance $(W=72, p=0.09)$. The values were separated at each contemporaneous sampling point except February 2015, when they converged at a value of around $15 \%$ (Fig. 6). More samples, could further resolve this potential difference. All pelagic predatory fishes showed minimal temporal differences in carbon isotope composition, although the values measured in October were overall slightly lower, largely driven by one C. hippurus. S. sierra show no obvious change in isotope composition through time, having similar within-month composition regardless of sample location. C. hippurus and T. albacares are relatively depleted in both isotopes compared to $S$. sierra, with the exception of $T$. albacares samples in February 2015, which are isotopically indistinguishable from $S$. sierra. There are too few months of sampling, however, to draw either statistically robust conclusions, or inferences on lag time between these predators and smaller fish that constitute their potential prey. Interestingly, both carbon and nitrogen isotope composition in all pelagic predators sampled (C. hippurus, S. sierra, and T. albacares) appear largely unrelated to their reported location of capture (Fig. 6). 
576 Figure 6. Time series of (A) lipid-corrected carbon isotope values, and (B) mass-corrected nitrogen

577 isotope values in piscivorous fishes; squares are mahi mahi, triangles are sierra mackerel, and

578 crosses are yellowfin tuna; red is the Gulf of Chiriquí, green is the open Pacific Ocean, and blue is the 579 Bay of Panama.

580

581

3. Discussion

582

Ecosystem structure and nutrient flows can be measured and estimated by coupling stable isotope analyses to biological and environmental data. We describe the trophic structure and temporal nutrient transfer of a pelagic ecosystem subject to seasonal upwelling in the Tropical Eastern Pacific, covering size classes over three orders of magnitude. Here, we found low estimates of tissue-diet fractionation and of predator-prey mass ratio, which suggest high trophic transfer efficiency and rapid trophic assimilation of nutrients within this ecosystem (Barnes et al., 2010; Jennings et al., 2002). We see very rapid nutrient movements of between 0.5 to 1.0 month on average per trophic level. While there are many estimates of production and biomass residence rate per unit of time (e.g. Gascuel et al., 2008; Maureaud et al., 2017; Quillfeldt et al., 2015), particularly for individual species, there are few direct measurements of the duration of nutrient movement between trophic levels within marine ecosystems.

We found no strong drivers that spatially covary with the stable isotope composition of plankton across the Bay of Panama during the non-upwelling season. The overall isoscapes of the Bay of

597 Panama were relatively spatially homogenous in both phyto- and zooplankton samples, although

598 they showed localised depletions in $\delta^{13} \mathrm{C}$ and, most strongly, $\delta^{15} \mathrm{~N}$ values. The depletions were generally quite close to shore, and likely caused by blooms of nitrogen-fixing cyanobacteria (Capone et al., 2005; Takai et al., 2000). This finding has implications for isoscapes based on POM and plankton measurements, as the localised variability can be high. If possible, time-series replicates should be taken to gauge the persistence of extreme isotopic values before inferences can be made on the influence of these values throughout the ecosystem. 
606

607

608

609

610

611

612

613

614

615

616

617

618

619

620

621

622

623

624

625

626

627

628

629

630

631

632

633

634

635

636

637

638

639

of isotopic composition than phytoplankton, and integration of a range of taxa and compositions in the primary producers (Smyntek et al., 2007). Isotopic fractionation between primary producers and herbivores is expected to be lower than the commonly used ecosystem averages of c. $3.4 \%$ in ${ }^{15} \mathrm{~N}$ and c. $1 \%$ in ${ }^{13} \mathrm{C}$ (Sweeting et al., 2007; Vander Zanden and Rasmussen, 1999). This minimal spacing may be caused by a number of factors, such as low prey nitrogen content (Gaye-Siessegger et al., 2003), high nutrient availability (particularly in nutrient-rich, e.g. upwelled, waters), or abundance of large or colonial herbivores such as salps (Adams and Sterner, 2000; Henschke et al., 2015). Similar carbon and nitrogen isotope separations to those measured in this study $\left(\delta^{13} \mathrm{C}: 2.9 \pm 0.03, \delta^{15} \mathrm{~N}: 2.1\right.$ \pm 0.12 ) have been recorded between phyto- and zooplankton fractions that were split by size at or below $200 \mu \mathrm{m}$, with minimally enriched isotope ratio values in the larger size classes (Fry and Quinones, 1994; Goering et al., 1990; Sholto-Douglas et al., 1991). The $\Delta$ values from this study suggest the $\delta^{15} \mathrm{~N}$ fractionation between primary producers and primary consumers is towards the low end of ecosystem estimates, in accord with that observed between primary producers and herbivores elsewhere, but relatively high $\delta^{13} \mathrm{C}$ fractionation. While the zooplankton fraction was corrected for lipid content, the complex carbohydrates in the phytoplankton mean that arithmetic lipid correction is not possible; we suggest that the carbohydrate and lipid content of the phytoplankton is the cause of this relatively high $\Delta^{13} \mathrm{C}$ value between phyto- and zooplankton. The extreme depleted values we record are similarly low for both size fractions of plankton (Table 2, Figs 2 and 3). These low values may be caused by localised nitrogen-fixation by cyanobacteria, such as Trichodesmium (Capone et al., 2005; Montoya, 2008), although it is possible that they are linked to anthropogenic nitrogen inputs as these can also have values close to $0 \% \delta^{15} \mathrm{~N}$ (Morin et al., 2009). The small, significant relationship between $\delta^{15} \mathrm{~N}$ and marginally significant relationship between $\delta^{13} \mathrm{C}$ values in zooplankton and proximity to settlements (driven by values in northern Las Perlas Archipelago) suggests that there may be some very localised effect of anthropogenic nutrients, possibly over short timespans as it is not apparent in the phytoplankton component, indicating that the zooplankton isotopic depletion may be due to nutrients from one to two months earlier. Interestingly, we do not find any isotopic effect of proximity to Panama City, indicating that nutrients from the City and the Canal may sediment rapidly out of pelagic circulation, may be mixed by the strong tidal currents, or may be swept rapidly out from the Bay for deposition elsewhere (Thompson, 2007). The Bay of Panama is subject to strong tidal flushing due to the large, regular, semidiurnal tides (Kirkpatrick, 1931), which may be the reason that no isotopic trace of the City is observed here. Alternatively, as suggested in the upwelling system off Morocco (Waser et al., 2000), low $\delta^{15} \mathrm{~N}$ values may be due to primary producers using more ammonium than nitrate for growth, where ammonium may originate from upwelled waters, or from bacterial action in waters with low 
oxygen content (McMahon et al., 2013). The lack of relationship between distances to anthropogenic nutrient sources and stable isotope compositions in phytoplankton is indicative that diazotrophs or ammonium uptake may be more likely explanations for the very depleted values of both $\delta^{13} \mathrm{C}$ and $\delta^{15} \mathrm{~N}$.

\subsection{Ecosystem structure}

Simplification of complex and difficult to describe food web interactions into nutrient fluxes through trophic levels of an ecosystem enables understanding of the ecological processes structuring that ecosystem; stable isotope data provide information on such nutrient fluxes with relatively simple sampling requirements. Both for management of marine resources and for behavioural and dietary ecology, it is important to know the connectivity of an ecosystem and its inhabitants to different nutrient sources, for example pelagic versus benthic production (France, 1995; France and Peters, 1997; Trueman et al., 2014). Based on the stable isotope compositions of carbon and nitrogen, the Bay of Panama pelagic ecosystem shows relatively linear, positive relationships with size and trophic level, suggesting a size-structured ecosystem. The patterns of nutrient transfer imply a single isotopic nutrient source with minimal evidence of modularity or separate food chains between open pelagic, reef-dwelling, or benthopelagic organisms. Enrichment along the $\delta^{15} \mathrm{~N}$ axis is related to trophic level (Fig. 3), with planktivores feeding above plankton, and predators feeding above planktivores. Enrichment in $\delta^{13} \mathrm{C}$ also has a trophic component, but the most enriched consumers tend to be those using a combination of benthic and pelagic resources, $C$. mysticetus, $C$. panamensis, E. labriformis, and M. altipinnis (Bayliff, 1963; Craig et al., 1999). Exclusively pelagic-feeding fishes had lower $\delta^{13} C^{\prime}$ values than those fishes whose diet may also contain some benthic prey items. Due to bacterial remineralisation, benthic ecosystem components are often enriched in the heavy isotopes of carbon (and sometimes nitrogen) relative to fresh, pelagic production (Cavan et al., 2017; France, 1995). Pacific anchoveta foraging on benthic diatoms in shallow waters, for which they have specialised gill rakers (Bayliff, 1963), and starry grouper, Pacific graysby, and tallfin croaker feeding on benthic fishes and invertebrates might be expected to show higher carbon isotope values than the measured pelagic fishes, as we observed in this study. These fishes were all, however, sampled towards the end of, or immediately following, upwelling season, which resulted in higher $\delta^{13} \mathrm{C}$ values in rainbow chub; the enrichment seen in benthopelagic-feeding fishes could therefore be due to benthic nutrient input, upwelled nutrient enrichment, or a combination of both although the results should be treated with caution because of the low number and irregular temporal sampling. The $\delta^{13} C^{\prime}$ values of $C$. mysticetus were, however, higher than those of contemporaneous $K$. ocyurus, 
which suggests a component of benthic feeding in the isotopic composition of the anchoveta. We therefore suggest that relatively elevated values of $\delta^{13} \mathrm{C}$ are likely to be a good indicator of benthic nutrient use in this system, with relatively lower values indicative of a more pelagic feeding strategy. This enrichment in ${ }^{13} \mathrm{C}$ composition from pelagic- to benthic-feeding organisms is a commonly observed trait in marine systems (Duffill Telsnig et al., 2018; e.g. France, 1995; Trueman et al., 2014). The lack of difference between $K$. ocyurus and $C$. mysticetus $\delta^{15} \mathrm{~N}$ values also suggests that these fishes feed at a very similar trophic position in the ecosystem, which implies greater algal use by rainbow chub or greater zooplankton consumption by Pacific anchoveta than recorded by previous studies (Bayliff, 1963; Dominici-Arosemena and Wolff, 2006). Greater zooplanktivory in C. mysticetus might also explain the large TDF (4.3\%) in $\Delta^{15} \mathrm{~N}$ between TL2-3.

\subsection{Predatory fish ecology}

Temporal similarity in the stable isotope composition of piscivorous fishes, particularly between sierra mackerel individuals, despite putative spatial segregation could indicate one of four issues:

a) misreporting of capture location,

b) fishes captured in the Gulf of Chiriquí or the open Pacific Ocean were very recent migrants from the Bay of Panama,

c) the Bay of Panama is the primary driver of pelagic environmental conditions (Alory et al., 2012; Legeckis, 1988; McCreary et al., 1989) and therefore nutrient source for this part of the TEP, influencing the stable isotope composition of the open Pacific Ocean and into the Gulf of Chiriquí, or

d) seasonal thermocline shoaling in the south-eastern part of the Gulf of Chiriquí, while weaker than the upwelling in the Gulf of Panama (Tao et al., 2013), may result in similarity in carbon and nitrogen stable isotope composition between animals feeding in each Gulf.

Migratory C. hippurus and T. albacares had a range of $\delta^{15} \mathrm{~N}$ values that were not correlated with their size, and so more likely related to their area of feeding. The piscivorous fishes, C. hippurus, S. sierra, and T. albacares, had temporally similar $\delta^{13} C^{\prime}$ values from March 2014 to February 2015. Following correction to a mean mass for all piscivores, both C. hippurus and T. albacares were, however, depleted in ${ }^{15} \mathrm{~N}$ relative to $S$. sierra when considering the entire time series. T. albacares that were sampled during February 2015, however, in the upwelling season, overlapped entirely in their nitrogen isotope composition with that of $S$. sierra. The similarity between these two species, with the S. sierra all resident in the Bay of Panama at this time, might suggest that the capture location of 
the tuna was misreported (e.g. erroneously reported as either Bay of Panama or Gulf of Chiriquí, see appendix), and that these predatory fishes had converged on the productive upwelling zone at this time, integrating upwelled nutrients from their prey. Capture locations were assigned to a broad oceanographic area (Bay of Panama, Gulf of Chiriquí, open Pacific Ocean) based on reported capture location by the fish market stall holder, therefore analyses based on these locations may not be as robust as analysis of time, which was firmly established. Alternatively, given the extension of upwelled waters westward to $95^{\circ} \mathrm{W}$, and over $1500 \mathrm{~km}$ from the Gulf of Panama during this season (Alory et al., 2012; Legeckis, 1988), the T. albacares may have been caught in Chiriquí after integrating upwelled nutrients that originated in the Bay of Panama then flowed rapidly through this area of the TEP. The relative depletion of T. albacares and C. hippurus in ${ }^{15} \mathrm{~N}$ suggests that $\delta^{15} \mathrm{~N}$ values are a better measure than $\delta^{13} C^{\prime}$ values of local versus open ocean production source in migratory fishes around the Panama area. Both explanations suggest the Bay of Panama is a productivity hotspot within the TEP during upwelling season. T. albacares appear to be sufficiently reliant upon upwelling and integrate local $\delta^{15} \mathrm{~N}$ values from upwelling-sourced nutrients sufficiently rapidly to be isotopically indistinguishable from local piscivorous fishes within 1.5 to 3 months of upwelling onset based on our calculated nutrient transfer times between trophic levels within this ecosystem.

We find it less likely that the seasonal shallowing of the Gulf of Chiriquí thermocline would cause similarity in carbon and nitrogen isotope compositions between animals caught here and in the Gulf of Panama, as previous research on oxygen isotope composition in bivalves between these areas did not observe similarity (Tao et al., 2013). It is, however, possible that organic isotope measurements in more rapidly grown tissues may find the smaller influence of temperature and nutrient chemistry than that observed in slower growing, inorganic bivalve minerals with somewhat more dampened signals of environmental variation. For future work on the reliance of migratory pelagic fishes on upwelled nutrients, more samples taken from fishes at known locations and over longer, more frequently sampled time scales within the Bay of Panama, the Gulf of Chiriquí, and in the open Pacific Ocean would be necessary to quantify the magnitude and timing of changes in isotopic composition of migratory predators that are due to feeding on upwelling-sourced nutrients. Fin clips, scales, or muscle biopsies would be useful means of gaining samples from catch-and-release sportfished species such as T. albacares and C. hippurus (Williams et al., 2015). 
Empirical measurements of the timing of nutrient transfer are lacking above the single species level, outside of experimental systems, and are largely absent for marine ecosystems. We found that the isotopic composition of rainbow chub measured monthly throughout the year in Las Perlas Archipelago is correlated with mean monthly sea surface temperature records with a lag of one to two months. Marine baseline carbon isotope values on a broad geographic scale are strongly linked to sea surface temperature (Lara et al., 2010; Magozzi et al., 2017; Tagliabue and Bopp, 2008), which are subsequently integrated through the trophic web. The isotopic composition of higher trophic level consumers is therefore linked to the location and environmental conditions of the ecosystem in which the consumers' tissues were grown (Bowen, 2010; Hobson, 1999; West et al., 2006). The significant negative correlation between $K$. ocyurus $\delta^{13} \mathrm{C}$ values and SST, with a one- to two-month lag, indicates a nutrient transfer time of one to two months from primary producers (TL1) to planktivorous (TL3) fishes, thus a mean transition time of 1 TL per $0.5-1$ month in this tropical pelagic ecosystem. Similarly rapid integration of upwelled nutrients has also been measured in other warm water systems, including Lake Tanganyika and the South China Sea (Jiang and Wang, 2018; O'Reilly et al., 2002). This short period of time indicates a rapid transition of nutrients through the Bay of Panama Ecosystem, but it would be useful to collect a longer time series to enable tests of inter-seasonal variability in nutrient incorporation times.

The relatively low predator-prey mass ratio (PPMR) calculated for resident fishes of $376: 1$, may be indicative of inefficient, although rapid, transition of nutrients through the ecosystem (Barnes et al., 2010; Trebilco et al., 2013). The maximum trophic level of 6.2 indicates that this ecosystem supports a relatively inefficient, long trophic chain within this ecosystem with multiple discrete trophic levels. To confirm and clarify the full temporal extent of the cycles, however, it would be useful to obtain a longer time series. Knowledge of temporal dynamics in nutrient source and integration time are essential for the assessment of source contributions to the ecosystem and its components, determination of temporal stability in nutrient transfer, and for prediction of responses to change (Jennings et al., 2008; O’Reilly et al., 2002; Woodland et al., 2012).

The calculated PPMR of 113:1 for all fishes is relatively low for marine ecosystem PPMR measurements globally (Barnes et al., 2010), which, in combination with the low tissue-diet fractionation (TDF) in $\delta^{15} \mathrm{~N}$, suggests that the fish component of the pelagic system within the Bay of Panama is potentially inefficient in trophic transfer, likely with multiple trophic levels, and implies high species richness between predators and prey (Barnes et al., 2010; Jennings et al., 2002; Trebilco et al., 2013). Additionally, given that the PPMR value is lower when migrant fishes are included, this 
implies that the migratory predators may be consuming larger, more predatory species that are relatively similar in size to their predators. Reducing the $\Delta^{15} \mathrm{~N}$ (TDF) between trophic levels, or reduction of the slope of the relationship between $\delta^{15} \mathrm{~N}$ and $\log _{2}$ mass have similar effects, both increasing the efficiency of nutrient transfer by effectively shortening the food chain length, meaning that, for a given change in mass, there will be a smaller change in trophic level, implying a less efficient use of the prey resource (Barnes et al., 2010). Measurements of $\delta^{15} \mathrm{~N}-\log _{2}$ mass within the entire ecosystem, and between known resident fishes in the Bay of Panama both increase the TDF relative to that of the entire fish community, thereby increasing the PPMR to $375: 1$ for the whole ecosystem, or 376:1 for resident fishes. For the resident fishes, the slope is slightly reduced relative to that of the whole ecosystem and to the entire fish community, also indicating greater nutrient transfer efficiency. The measured slopes are similar to those of North Sea fishes (slope = 0.335, (Jennings et al., 2001)), suggesting similar size structuring between the two ecosystems, but much higher than the slope of 0.263 measured in the tropical upwelling system in the Western Arabian Sea (Al-Habsi et al., 2008). The PPMR values (all fish $=113: 1$, resident fish $=376: 1$, whole ecosystem $=375: 1)$ in the Bay of Panama are, however, orders of magnitude lower than the majority of literature studies. Reported values include the North Sea fish community (PPMR $=1136: 1$ ), which is a productive and highly seasonal temperate system, the southwest subtropical Pacific near New Caledonia (PPMR = 148,000:1) (Hunt et al., 2015), and in the seasonal upwelling systems of the Western Arabian Sea (PPMR = 7792:1), along the Atlantic margin of the Iberian Peninsula (PPMR = c. 200,000:1), and, more specifically, the Galician upwelling system (PPMR $=4500: 1$ ) (Bode et al., 2007, 2003), although the latter two studies included a much broader range or organism sizes. The Bay of Panama results are quite low in a global context (Al-Habsi et al., 2008; Barnes et al., 2010), and indicative of rapid, although somewhat inefficient nutrient transfer from low to high trophic levels within this ecosystem. Compared to other pelagic systems, these low values suggest a relatively midlength and bottom-heavy pyramid or column-shaped ecosystem, indicative of nutrient export at low trophic levels, and import at higher trophic levels (Trebilco et al., 2013). This result supports the relationship between sea surface temperature and $\delta^{13} \mathrm{C}$ values in resident pelagic planktivores which suggest a mean nutrient transfer time of 1 TL per $0.5-1$ month within this ecosystem.

\section{Conclusions}

Spatial phyto- and zooplankton carbon and nitrogen isotope compositions are relatively homogenous in non-upwelling season, but with localised point depletion, likely due to blooms of nitrifying primary producers or to localised uptake of ammonium rather than nitrate as a growth 
medium. As this study cannot provide information on the temporal stability at the base of the ecosystem, isoscapes should also be measured during upwelling to determine the extent of isotopic change due to changes in the environmental conditions, nutrient availability, and different isotopic composition of upwelled nutrients. This information would provide a more holistic view of the spatio-temporal influence of upwelling on ecosystem structure and nutrient transfer, and on the degree of integrated stable isotope signal dampening from primary production to higher trophic levels.

Upwelling-driven temperature changes and nutrients are recorded in the $\delta^{13} \mathrm{C}$ values of resident fishes and integrated rapidly into the tissues of migrant consumers. The nutrient transfer time of carbon sources is c. 0.5 to 1 month per trophic level for this tropical pelagic ecosystem. Accounting for such lags in temporal dynamics of nutrient transfer and stable isotope composition can dramatically improve estimates of nutrient sources and timing of production at different levels of an ecosystem.

Together, isoscapes and $K$. ocyurus stable isotope compositions set a geographic, non-upwelling baseline and a temporal proxy baseline for the characterization and comparison of resident versus migrant organisms, pelagic versus benthic feeding, and upwelled versus non-upwelled nutrient use. The isotopic compositions, tissue-diet fractionation factors, and duration of nutrient transfer are essential but difficult to obtain information for comparative studies of pelagic, tropical, and upwelling-influenced marine ecosystems.

This ecosystem has a linear trophic structure, recorded in its $\delta^{15} \mathrm{~N}$ values, with both benthic and upwelling enrichment in $\delta^{13} \mathrm{C}$ values. Carbon stable isotope composition is therefore useful to track pelagic versus benthic nutrient sources, and particularly to track upwelled nutrient use through time. Nitrogen stable isotope composition of migratory fishes, however, may be a better indicator of recent local versus imported nutrient use, i.e. whether the fish has fed within this ecosystem in recent months, or whether it is newly arrived.

The predator-prey mass ratios calculated in the system, in combination with the estimated maximum trophic level of 6.2, suggest that the Bay of Panama pelagic ecosystem has a relatively long trophic chain, with inefficient nutrient transfer between trophic levels. This result should be considered in the context of ecosystem management, particularly for fisheries, during less productive conditions such as years when El Niño events prevent upwelling in the area.

Given the taxonomically independent relationship between body size and trophic level, as measured in $\delta^{15} \mathrm{~N}$ values within organisms resident in this pelagic ecosystem, we suggest that size is a driving 
factor in determining behavioural and trophic ecology in pelagic animals within this area, and that size-based models and trophic ecology should be key in ecosystem models and impact assessments.

\section{Acknowledgements}

KMM was funded through a Smithsonian Stable Isotope Postdoctoral Fellowship. JNA was funded through the Smithsonian Tropical Research Institute Short-Term Fellowship Program. Thanks to the staff of the STRI Stable Isotope Laboratory, particularly Dayana Agudo, to Anthony Coates at STRI for fieldwork funding, to Jean Philippe Belanger for assistance with sample preparation, and to ProMarina S.A. for access to samples. . We would also like to thank the two anonymous reviewers whose comments and suggestions have greatly improved this manuscript. Samples were collected in the Bay of Panama under an ARAP permit.

\section{References}

Adams, T.S., Sterner, R.W., 2000. The effect of dietary nitrogen content on trophic level ${ }^{15} \mathrm{~N}$ enrichment. Limnol. Oceanogr. 45, 601-607. doi:10.4319/lo.2000.45.3.0601

Al-Habsi, S., Sweeting, C., Polunin, N., Graham, N., 2008. $\delta^{15} \mathrm{~N}$ and $\delta^{13} \mathrm{C}$ elucidation of size-structured food webs in a Western Arabian Sea demersal trawl assemblage. Mar. Ecol. Prog. Ser. 353, 5563. doi:10.3354/meps07167

Alory, G., Maes, C., Delcroix, T., Reul, N., Illig, S., 2012. Seasonal dynamics of sea surface salinity off Panama: The far Eastern Pacific Fresh Pool. J. Geophys. Res. Ocean. 117. doi:10.1029/2011JC007802

Altabet, M.A., Pilskaln, C., Thunell, R., Pride, C., Sigman, D., Chavez, F., Francois, R., 1999. The nitrogen isotope biogeochemistry of sinking particles from the margin of the Eastern North Pacific. Deep Sea Res. Part I Oceanogr. Res. Pap. 46, 655-679.

Amante, C., Eakins, B.W., 2009. NOAA Technical Memorandum NESDIS NGDC-24 ETOPO1 1 ArcMinute Global Relief Model: Procedures, Data Sources, and Analysis.

Argüelles, J., Lorrain, A., Cherel, Y., Graco, M., Tafur, R., Alegre, A., Espinoza, P., Taipe, A., Ayón, P., Bertrand, A., 2012. Tracking habitat and resource use for the jumbo squid Dosidicus gigas: a stable isotope analysis in the Northern Humboldt Current System. Mar. Biol. 159, 2105-2116. doi:10.1007/s00227-012-1998-2 
Barnes, C., Maxwell, D., Reuman, D.C., Jennings, S., 2010. Global patterns in predator-prey size relationships reveal size dependency of trophic transfer efficiency. Ecology 91, 222-232. doi:10.1890/08-2061.1

Bayliff, W.H., 1963. The food and feeding habits of the anchoveta, Cetengraulis mysticetus, in the Gulf of Panama. Inter-American Trop. Tuna Comm. Bull. 7, 397-459.

Blanchard, J.L., Heneghan, R.F., Everett, J.D., Trebilco, R., Richardson, A.J., 2017. From Bacteria to Whales: Using Functional Size Spectra to Model Marine Ecosystems. Trends Ecol. Evol. 32, 174186. doi:10.1016/j.tree.2016.12.003

Block, B.A., Jonsen, I.D., Jorgensen, S.J., Winship, A.J., Shaffer, S.A., Bograd, S.J., Hazen, E.L., Foley, D.G., Breed, G.A., Harrison, A.-L., Ganong, J.E., Swithenbank, A., Castleton, M., Dewar, H., Mate, B.R., Shillinger, G.L., Schaefer, K.M., Benson, S.R., Weise, M.J., Henry, R.W., Costa, D.P., 2011. Tracking apex marine predator movements in a dynamic ocean. Nature 475, 86-90. doi:10.1038/nature10082

Bode, A., Alvarez-Ossorio, M.T., Cunha, M.E., Garrido, S., Peleteiro, J.B., Porteiro, C., Valdés, L., Varela, M., 2007. Stable nitrogen isotope studies of the pelagic food web on the Atlantic shelf of the Iberian Peninsula. Prog. Oceanogr. 74, 115-131. doi:10.1016/J.POCEAN.2007.04.005

Bode, A., Carrera, P., Lens, S., 2003. The pelagic foodweb in the upwelling ecosystem of Galicia (NW Spain) during spring: natural abundance of stable carbon and nitrogen isotopes. ICES J. Mar. Sci. 60, 11-22. doi:10.1006/jmsc.2002.1326

Bode, A., Casas, B., Fernandez, E., Maranon, E., Serret, P., Varela, M., 1996. Phytoplankton biomass and production in shelf waters off NW Spain: spatial and seasonal variability in relation to upwelling. Hydrobiologia 341, 225-234.

Bowen, G.J., 2010. Isoscapes: Spatial Pattern in Isotopic Biogeochemistry. Annu. Rev. Earth Planet. Sci. 38, 161-187. doi:10.1146/annurev-earth-040809-152429

Capone, D.G., Burns, James A, Montoya, Joseph P, Subramaniam, Ajit, Mahaffey, Claire, Gunderson, Troy, Michaels, Anthony F, Carpenter, E.J., Capone, C.:, Burns, J A, Montoya, J P, Subramaniam, A, Mahaffey, C, Gunderson, T, Michaels, A F, 2005. Nitrogen fixation by Trichodesmium spp.: An important source of new nitrogen to the tropical and subtropical North Atlantic Ocean. Global Biogeochem. Cycles 19, GB2024. doi:10.1029/2004GB002331

Cavan, E.L., Trimmer, M., Shelley, F., Sanders, R., 2017. Remineralization of particulate organic carbon in an ocean oxygen minimum zone. Nat. Commun. 8, 14847. 
doi:10.1038/ncomms14847

897

898

899

900

901

902

903

904

905

906

907

908

909

910

911

912

913

914

915

916

917

918

919

920

921

922

923

CeDePesca, 2015. Small Pelagic Fishery in Panama, Stock Assessment and Recommendations for a Management Plant Prepared by CeDePesca Technical Team in cooperation with the Aquatic Resources Authority of Panama (ARAP) and Promarina SA. Panama.

Chavez, F.P., Messié, M., 2009. A comparison of Eastern Boundary Upwelling Ecosystems. Prog. Oceanogr. 83, 80-96. doi:10.1016/J.POCEAN.2009.07.032

Chavez, F.P., Ryan, J., Lluch-Cota, S.E., Ñiquen C., M., 2003. From Anchovies to Sardines and Back: Multidecadal Change in the Pacific Ocean. Science (80-. ). 299, 217-221. doi:10.1126/science.1075880

Coelho-Souza, S.A., López, M.S., Guimarães, J.R.D., Coutinho, R., Candella, R.N., 2012. Biophysical interactions in the Cabo Frio upwelling system, southeastern Brazil. Brazilian J. Oceanogr. 60, 353-365. doi:10.1590/S1679-87592012000300008

Collette, B.B., Nauen, C.E., 1983. FAO species catalogue. Vol. 2. Scombrids of the world : an annotated and illustrated catalogue of tunas, mackerels, bonitos, and related species known to date. United Nations Development Programme, Roma.

Craig, M.T., Pondella, D.J., Hafner, J.C., 1999. Analysis of age and growth in two Eastern Pacific groupers (Serranidae: Epinephelinae). Bull. Mar. Sci. 65, 807-814.

Csirke, J., Tandstad, M., 2005. Review of the state of world marine fishery resources. B13. Eastern Central Pacific FAO Statistical Area 77. Roma.

Cury, P., Bakun, A., Crawford, R.J.M., Jarre, A., Quiñones, R.A., Shannon, L.J., Verheye, H.M., 2000. Small pelagics in upwelling systems: patterns of interaction and structural changes in "waspwaist" ecosystems. ICES J. Mar. Sci. 57, 603-618. doi:10.1006/jmsc.2000.0712

Cushing, D.H., 1971. Upwelling and the Production of Fish. Adv. Mar. Biol. 9, 255-334. doi:10.1016/S0065-2881(08)60344-2

D’Croz, L., O’Dea, A., 2009. Nutrient and Chlorophyll Dynamics in Pacific Central America (Panama), in: Proceedings of the Smithsonian Marine Science Symposium. Smithsonian Institute, pp. 335344.

D'Croz, L., O'Dea, A., 2007. Variability in upwelling along the Pacific shelf of Panama and implications for the distribution of nutrients and chlorophyll. stuarine, Coast. Shelf Sci. 73, 325-340. doi:10.1016/j.ecss.2007.01.013 
D'Croz, L.D., Robertson, D.R., 1997. Coastal oceanographic conditions affecting coral reefs on both sides of the Isthmus of Panama, in: Proc. 8th Int. Coral Reef Sym. 2. pp. 2053-2058.

Dewar, H., Prince, E.D., Musyl, M.K., Brill, R.W., Sepulveda, C., Luo, J., Foley, D., Orbesen, E.S., Domeier, M.L., Nasby-Lucas, N., Snodgrass, D., Laurs, R.M., Hoolihan, J.P., Block, B.A., Mcnaughton, L.M., 2011. Movements and behaviors of swordfish in the Atlantic and Pacific Oceans examined using pop-up satellite archival tags. Fish. Oceanogr. 20, 219-241. doi:10.1111/j.1365-2419.2011.00581.x

Domínguez López, M., Uribe Alcocer, M., Díaz Jaimes, P., 2010. Phylogeography and historical demography of the Pacific Sierra mackerel (Scomberomorus sierra) in the Eastern Pacific. BMC Genet. 11, 34. doi:10.1186/1471-2156-11-34

Dominici-Arosemena, A., Wolff, M., 2006. Reef fish community structure in the Tropical Eastern Pacific (Panamá): living on a relatively stable rocky reef environment. Helgol. Mar. Res. 60, 287-305. doi:10.1007/s10152-006-0045-4

Dominici-Arosemena, A., Wolff, M., 2005. Reef Fish Community Structure in Bocas del Toro (Caribbean, Panama): Gradients in Habitat Complexity and Exposure. Caribb. J. Sci. 41, 613637.

Duarte, L.O., García, C.B., 2004. Trophic role of small pelagic fishes in a tropical upwelling ecosystem. Ecol. Modell. 172, 323-338. doi:10.1016/J.ECOLMODEL.2003.09.014

Duffill Telsnig, J.I., Jennings, S., Mill, A.C., Walker, N.D., Parnell, A.C., Polunin, N.V.C., 2018. Estimating contributions of pelagic and benthic pathways to consumer production in coupled marine food webs. J. Anim. Ecol. 88, 1365-2656.12929. doi:10.1111/1365-2656.12929

Ekau, W., Auel, H., Hagen, W., Koppelmann, R., Wasmund, N., Bohata, K., Buchholz, F., Geist, S., Martin, B., Schukat, A., Verheye, H.M., Werner, T., 2018. Pelagic key species and mechanisms driving energy flows in the northern Benguela upwelling ecosystem and their feedback into biogeochemical cycles. J. Mar. Syst. 188, 49-62. doi:10.1016/J.JMARSYS.2018.03.001

Fiedler, P.C., Talley, L.D., 2006. Hydrography of the eastern tropical Pacific: A review. Prog. Oceanogr. 69, 143-180. doi:10.1016/J.POCEAN.2006.03.008

Fischer, W., Krupp, F., Schneider, W., Sommer, C., Carpenter, K.E., Niem, V.H., 1995. Guia FAO para la identificación de especies para los fines de la pesca. Pacifico centro-oriental Volumen III. Vertebrados - Parte 2. Organización de las Naciones Unidas para la Agricultura y la Alimentación, Roma. 
France, R.L., 1995. Carbon-13 enrichment in benthic compared to planktonic algae: foodweb implications. Mar. Ecol. Prog. Ser. 124, 307-312.

France, R.L., Peters, R.H., 1997. Ecosystem differences in the trophic enrichment of ${ }^{13} \mathrm{C}$ in aquatic food webs. Can. J. Fish. Aquat. Sci. 54, 1255-1258.

Fry, B., Quinones, R.B., 1994. Biomass spectra and stable isotope indicators of trophic level in zooplankton of the northwest Atlantic. Mar. Ecol. Prog. Ser. 112, 201-204.

Fu, G., Baith, K.S., McClain, C.R., 1998. SeaDAS: The SeaWiFS Data Analysis System, in: Proceedings of "The 4th Pacific Ocean Remote Sensing Conference", Qingdao, China, July 28-31, 1998. Qingdao, pp. 73-79.

Gascuel, D., Morissette, L., Palomares, M.L.D., Christensen, V., 2008. Trophic flow kinetics in marine ecosystems: Toward a theoretical approach to ecosystem functioning. Ecol. Modell. 217, 3347. doi:10.1016/J.ECOLMODEL.2008.05.012

Gaye-Siessegger, J., Focken, U., Abel, H.J., Becker, K., 2003. Feeding level and diet quality influence trophic shift of $\mathrm{C}$ and $\mathrm{N}$ isotopes in Nile tilapia (Oreochromis niloticus (L.)). Isotopes Environ. Health Stud. 39, 125-134. doi:10.1080/1025601031000113556

Goericke, R., Fry, B., 1994. Variations of marine plankton $\delta 13 \mathrm{C}$ with latitude, temperature, and dissolved $\mathrm{CO}_{2}$ in the world ocean. Global Biogeochem. Cycles 8, 85-90. doi:10.1029/93GB03272

Goering, J., Alexander, V., Haubenstock, N., 1990. Seasonal variability of stable carbon and nitrogen isotope ratios of organisms in a North Pacific Bay. Estuar. Coast. Shelf Sci. 30, 239-260. doi:10.1016/0272-7714(90)90050-2

Gordon, H.R., Wang, M., 1994. Retrieval of water-leaving radiance and aerosol optical thickness over the oceans with SeaWiFS: a preliminary algorithm. Appl. Opt. 33, 443. doi:10.1364/AO.33.000443

Graham, B.S., Koch, P.L., Newsome, S.D., McMahon, K.W., Aurioles, D., 2010. Using Isoscapes to Trace the Movements and Foraging Behavior of Top Predators in Oceanic Ecosystems, in: West, J.B., Bowen, G.J., Dawson, T.E., Tu, K.P. (Eds.), Isoscapes: Understanding Movement, Pattern, and Process on Earth Through Isotope Mapping. Springer Netherlands, Dordrecht, pp. 299-318. doi:10.1007/978-90-481-3354-3

Gräler, B., Pebesma, E., Heuvelink, G., 2016. Spatio-Temporal Interpolation using gstat. R J. 8, 204218. 
1005

1006

1007

1008

1009

1010

1011

1012

1013

1014

1015

1016

1017

Henschke, N., Everett, J.D., Suthers, I.M., Smith, J.A., Hunt, B.P.V., Doblin, M.A., Taylor, M.D., 2015. Zooplankton trophic niches respond to different water types of the western Tasman Sea: A stable isotope analysis. Deep Sea Res. Part I Oceanogr. Res. Pap. 104, 1-8. doi:10.1016/J.DSR.2015.06.010

Hobson, K.A., 1999. Tracing origins and migration of wildlife using stable isotopes: a review. Oecologia 120, 314-326.

Hunt, B.P.V., Allain, V., Menkes, C., Lorrain, A., Graham, B., Rodier, M., Pagano, M., Carlotti, F., 2015. A coupled stable isotope-size spectrum approach to understanding pelagic food-web dynamics: A case study from the southwest sub-tropical Pacific. Deep Sea Res. Part II Top. Stud. Oceanogr. 113, 208-224. doi:10.1016/J.DSR2.2014.10.023

Jennings, S., Barnes, C., Sweeting, C.J., Polunin, N.V.C., 2008. Application of nitrogen stable isotope analysis in size-based marine food web and macroecological research. Rapid Commun. Mass Spectrom. 22, 1673-1680. doi:10.1002/rcm

Jennings, S., Pinnegar, J.K., Polunin, N.V.C., Boon, T.W., 2001. Weak cross-species relationships between body size and trophic level belie powerful size-based trophic structuring in fish communities. J. Anim. Ecol. 70, 934-944.

Jennings, S., Warr, K., Mackinson, S., 2002. Use of size-based production and stable isotope analyses to predict trophic transfer efficiencies and predator-prey body mass ratios in food webs. Mar. Ecol. Prog. Ser. 240, 11-20. doi:10.3354/meps240011

Jiang, R., Wang, Y.-S., 2018. Modeling the ecosystem response to summer coastal upwelling in the northern South China Sea. Oceanologia 60, 32-51. doi:10.1016/J.OCEANO.2017.05.004

Kiljunen, M., Grey, J., Sinisalo, T., Harrod, C., Immonen, H., Jones, R.I., 2006. A revised model for lipid-normalizing $\delta^{13} \mathrm{C}$ values from aquatic organisms, with implications for isotope mixing models. J. Appl. Ecol. 43, 1213-1222. doi:10.1111/j.1365-2664.2006.01224.x

Kirkpatrick, R.Z., 1931. Panama Tidal Differences. Hydrogr. Rev. VIII, 266-268.

Knudsen, S.W., Clements, K.D., 2013. Revision of the fish family Kyphosidae (Teleostei: Perciformes). Zootaxa 3751, 100. doi:10.11646/zootaxa.3751.1.1

Kruse, S., Pakhomov, E., Hunt, B., Chikaraishi, Y., Ogawa, N., Bathmann, U., 2015. Uncovering the trophic relationship between Themisto gaudichaudii and Salpa thompsoni in the Antarctic Polar Frontal Zone. Mar. Ecol. Prog. Ser. 529, 63-74. doi:10.3354/meps11288 
Lara, R.J., Alder, V., Franzosi, C. a., Kattner, G., 2010. Characteristics of suspended particulate organic matter in the southwestern Atlantic: Influence of temperature, nutrient and phytoplankton features on the stable isotope signature. J. Mar. Syst. 79, 199-209. doi:10.1016/j.jmarsys.2009.09.002

Lasso, J., Zapata, L., Zapata, L., 1999. Fisheries and biology of Coryphaena hippurus (Pisces: Coryphaenidae) in the Pacific coast of Colombia and Panama. Sci. Mar. 63, 387-399. doi:10.3989/scimar.1999.63n3-4387

Lauri, G., Ben, F.K., C., J.A., Quirós, M., Canto, G., Serrano, N., Franco, A., Arosemena, D.H., Acevedo, G., Justines, G., Pérez, H., Pinto, I.M., Corella, J., Posada, J.M., M., M.O., Machazeck, M., Van Eijs, S., 2014. Contribución de la pesca y la acuicultura a la seguridad alimentaria y el ingreso familiar en Centroamérica. Panamá. ORGANIZACIÓN DE LAS NACIONES UNIDAS PARA LA ALIMENTACIÓN Y LA AGRICULTURA - FAO.

Legeckis, R., 1988. Upwelling off the Gulfs of Panama and Papagayo in the tropical Pacific during March 1985. J. Geophys. Res. 93, 15485. doi:10.1029/JC093iC12p15485

Lehodey, P., 2001. The pelagic ecosystem of the tropical Pacific Ocean: dynamic spatial modelling and biological consequences of ENSO. Prog. Oceanogr. 49, 439-468. doi:10.1016/S00796611(01)00035-0

Lehodey, P., Alheit, J., Barange, M., Baumgartner, T., Beaugrand, G., Drinkwater, K., Fromentin, J.-M., Hare, S.R., Ottersen, G., Perry, R.I., Roy, C., van der Lingen, C.D., Werner, F., Lehodey, P., Alheit, J., Barange, M., Baumgartner, T., Beaugrand, G., Drinkwater, K., Fromentin, J.-M., Hare, S.R., Ottersen, G., Perry, R.I., Roy, C., Lingen, C.D. van der, Werner, F., 2006. Climate Variability, Fish, and Fisheries. J. Clim. 19, 5009-5030. doi:10.1175/JCLI3898.1

Lezama-Ochoa, N., Murua, H., Hall, M., Román, M., Ruiz, J., Vogel, N., Caballero, A., Sancristobal, I., 2017. Biodiversity and Habitat Characteristics of the Bycatch Assemblages in Fish Aggregating Devices (FADs) and School Sets in the Eastern Pacific Ocean. Front. Mar. Sci. 4, 265. doi:10.3389/fmars.2017.00265

Libes, S.M., Deuser, W.G., 1988. The isotope geochemistry of particulate nitrogen in the Peru upwelling area and the Gulf of Maine. Deep Sea Res. Part A. Oceanogr. Res. Pap. 35, 517-533. doi:10.1016/0198-0149(88)90129-X

Lopez-Lopez, L., Preciado, I., Muñoz, I., Decima, M., Molinero, J.C., Tel, E., 2017. Does upwelling intensity influence feeding habits and trophic position of planktivorous fish? Deep Sea Res. Part 
MacKenzie, K.M., Robertson, D.R., Adams, J.N., Altieri, A.H., Turner, B.L., 2019. Carbon and nitrogen stable isotope data from organisms in the Bay of Panama ecosystem - dataset. PANGAEA. doi:10.1594/PANGAEA.903842

MacKenzie, K.M., Trueman, C.N., Lucas, C.H., Bortoluzzi, J., 2017. The preparation of jellyfish for stable isotope analysis. Mar. Biol. 164, 219. doi:10.1007/s00227-017-3242-6

Madigan, D.J., Carlisle, A.B., Dewar, H., Snodgrass, O.E., Litvin, S.Y., Micheli, F., Block, B.A., 2012. Stable Isotope Analysis Challenges Wasp-Waist Food Web Assumptions in an Upwelling Pelagic Ecosystem. Sci. Rep. 2, 654. doi:10.1038/srep00654

Magozzi, S., Yool, A., Vander Zanden, H.B., Wunder, M.B., Trueman, C.N., 2017. Using ocean models to predict spatial and temporal variation in marine carbon isotopes. Ecosphere 8, e01763. doi:10.1002/ecs2.1763

Marra, J., Wiebe, P.H., B, J.K., Stepien, J.C., 1987. Primary production and grazing in the plankton of the Panama Bight. Bull. Mar. Sci. 40, 255-270.

Martin, S.L., Ballance, L.T., Groves, T., 2016. An Ecosystem Services Perspective for the Oceanic Eastern Tropical Pacific: Commercial Fisheries, Carbon Storage, Recreational Fishing, and Biodiversity. Front. Mar. Sci. 3, 50. doi:10.3389/fmars.2016.00050

Maureaud, A., Gascuel, D., Colléter, M., Palomares, M.L.D., Du Pontavice, H., Pauly, D., Cheung, W.W.L., 2017. Global change in the trophic functioning of marine food webs. PLoS One 12, e0182826. doi:10.1371/journal.pone.0182826

McCreary, J.P., Lee, H.S., Enfield, D.B., 1989. The response of the coastal ocean to strong offshore winds: With application to circulations in the Gulfs of Tehuantepec and Papagayo. J. Mar. Res. 47, 81-109.

McMahon, K.W., Hamady, L.L., Thorrold, S.R., 2013. A review of ecogeochemistry approaches to estimating movements of marine animals. Limnol. Oceanogr. 58, 697-714. doi:10.4319/lo.2013.58.2.0697

Miglietta, M.P., Rossi, M., Collin, R., 2008. Hydromedusa blooms and upwelling events in the Bay of Panama, Tropical East Pacific. J. Plankton Res. 30, 783-793. doi:10.1093/plankt/fbn038

Minami, H., Ogi, H., 1997. Determination of migratory dynamics of the sooty shearwater in the Pacific using stable carbon and nitrogen isotope analysis. Mar. Ecol. Prog. Ser. 158, 249-256. 
Molina-Ramírez, A., Cáceres, C., Romero-Romero, S., Bueno, J., González-Gordillo, J.I., Irigoien, X., Sostres, J., Bode, A., Mompeán, C., Fernández Puelles, M., Echevarria, F., Duarte, C.M., Acuña, J.L., 2015. Functional differences in the allometry of the water, carbon and nitrogen content of gelatinous organisms. J. Plankton Res. 37, 989-1000. doi:10.1093/plankt/fbv037

Moloney, C.L., Field, J.G., 1991. The size-based dynamics of plankton food webs. I. A simulation model of carbon and nitrogen flows. J. Plankton Res. 13, 1003-1038.

Montoya, J.P., 2008. Natural Abundance of ${ }^{15} \mathrm{~N}$ in Marine Planktonic Ecosystems, in: Stable Isotopes in Ecology and Environmental Science. Blackwell Publishing Ltd, Oxford, UK, pp. 176-201. doi:10.1002/9780470691854.ch7

Morin, S., Savarino, J., Frey, M.M., Domine, F., Jacobi, H.-W., Kaleschke, L., Martins, J.M.F., 2009. Comprehensive isotopic composition of atmospheric nitrate in the Atlantic Ocean boundary layer from $65^{\circ} \mathrm{S}$ to $79^{\circ} \mathrm{N}$. J. Geophys. Res. 114, D05303. doi:10.1029/2008JD010696

Moteki, M., Arai, M., Tsuchiya, K., Okamoto, H., 2001. Composition of piscine prey in the diet of large pelagic fish in the eastern tropical Pacific Ocean. Fish. Sci. 67, 1063-1074. doi:10.1046/j.14442906.2001.00362.x

O’Reilly, C.M., Hecky, R.E., Cohen, A.S., Plisnier, P.-D., 2002. Interpreting stable isotopes in food webs: Recognizing the role of time averaging at different trophic levels. Limnol. Oceanogr. 47, 306-309. doi:10.4319/lo.2002.47.1.0306

O’Reilly, J.E., Maritorena, S., Siegel, D.A., O’Brien, M.C., Toole, D., Mitchell, B.G., Kahru, M., Chavez, F.P., Strutton, P., Cota, G.F., Hooker, S.B., McClain, C.R., Carder, K.L., Müller-Karger, F., Harding, L., Magnuson, A., Phinney, D., Moore, G.F., Aiken, J., Arrigo, K.R., Letelier, R., Culver, M., 2000. SeaWiFS Post-Launch Calibration and Validation Analyses, Part 3, SeaWiFS Post-Launch Technical Report Series.

Olson, R.J., Boggs, C.H., 1986. Apex Predation by Yellowfin Tuna (Thunnus albacares): Independent Estimates from Gastric Evacuation and Stomach Contents, Bioenergetics, and Cesium Concentrations. Can. J. Fish. Aquat. Sci. 43, 1760-1775. doi:10.1139/f86-220

Pante, E., Simon-Bouhet, B., 2013. marmap: A Package for Importing, Plotting and Analyzing Bathymetric and Topographic Data in R. PLoS One 8, e73051. doi:10.1371/journal.pone.0073051 691. doi:10.1016/J.CAGEO.2004.03.012 
Pedraza, M.J., Díaz Ochoa, J.A., 2006. Sea level height, sea surface temperature, and tuna yields in the Panama bight during El Niño. Adv. Geosci. 6, 155-159.

Pennington, J.T., Mahoney, K.L., Kuwahara, V.S., Kolber, D.D., Calienes, R., Chavez, F.P., 2006. Primary production in the eastern tropical Pacific: A review. Prog. Oceanogr. 69, 285-317. doi:10.1016/J.POCEAN.2006.03.012

Quillfeldt, P., Ekschmitt, K., Brickle, P., McGill, R.A.R., Wolters, V., Dehnhard, N., Masello, J.F., 2015. Variability of higher trophic level stable isotope data in space and time - a case study in a marine ecosystem. Rapid Commun. Mass Spectrom. 29, 667-674. doi:10.1002/rcm.7145

R Development Core Team, R., 2011. R: A Language and Environment for Statistical Computing. R Found. Stat. Comput., R Foundation for Statistical Computing. doi:10.1007/978-3-540-74686-7

Reum, J.C.P., Holsman, K.K., Aydin, K.Y., Blanchard, J.L., Jennings, S., 2019. Energetically relevant predator-prey body mass ratios and their relationship with predator body size. Ecol. Evol. 9, 201-211. doi:10.1002/ece3.4715

Robertson, D.R., Allen, G.R., 2015. Shorefishes of the Tropical Eastern Pacific: online information system. Version 2.0.

Saetersdal, G., Bianchi, G., Strømme, T., Venema, S.C., 1999. The Dr. Fridtjof Nansen Programme 1975-1993 Investigations of fishery resources in developing regions History of the programme and review of results. FAO Fisheries Technical Paper No. 391. Rome.

Samuelsen, A., O’Brien, J.J., 2008. Wind-induced cross-shelf flux of water masses and organic matter at the Gulf of Tehuantepec. Deep Sea Res. Part I Oceanogr. Res. Pap. 55, 221-246. doi:10.1016/J.DSR.2007.11.007

Santos, A.M.P., Chícharo, A., Dos Santos, A., Moita, T., Oliveira, P.B., Peliz, Á., Ré, P., 2007. Physicalbiological interactions in the life history of small pelagic fish in the Western Iberia Upwelling Ecosystem. Prog. Oceanogr. 74, 192-209. doi:10.1016/J.POCEAN.2007.04.008

Shettle, E.P., Fenn, R.W., 1979. Models for the Aerosols for the Lower Atmosphere and the Effects of Humidity Variations on Their Optical Properties., AFGL-TR-79-0214 Environmental Research Papers No. 676.

Sholto-Douglas, A.D., Field, J.G., James, A.G., van de Merwe, N.J., $1991 .{ }^{13} \mathrm{C} /{ }^{12} \mathrm{C}$ and ${ }^{15} \mathrm{~N} /{ }^{14} \mathrm{~N}$ isotope ratios in the Southern Benguela Ecosystem: indicators of food web relationships among different size-classes of plankton and pelagic fish; differences between fish muscle and bone col. Mar. Ecol. Prog. Ser. 78, 23-31. 
Smyntek, P.M., Teece, M.A., Schulz, K.L., Thackeray, S.J., 2007. A standard protocol for stable isotope analysis of zooplankton in aquatic food web research using mass balance correction models. Limnol. Oceanogr. 52, 2135-2146.

Stuhldreier, I., Sánchez-Noguera, C., Rixen, T., Cortés, J., Morales, A., Wild, C., 2015. Effects of Seasonal Upwelling on Inorganic and Organic Matter Dynamics in the Water Column of Eastern Pacific Coral Reefs. PLoS One 10, e0142681. doi:10.1371/journal.pone.0142681

Sweeting, C.J., Barry, J., Barnes, C., Polunin, N.V.C., Jennings, S., 2007. Effects of body size and environment on diet-tissue $\delta^{15} \mathrm{~N}$ fractionation in fishes. J. Exp. Mar. Bio. Ecol. 340, 1-10. doi:10.1016/j.jembe.2006.07.023

Tagliabue, A., Bopp, L., 2008. Towards understanding global variability in ocean carbon-13. Global Biogeochem. Cycles 22, 1-13. doi:10.1029/2007GB003037

Takai, N., Onaka, S., Ikeda, Y., Yatsu, A., 2000. Geographical variations in carbon and nitrogen stable isotope ratios in squid. J. Mar. Biol. Assoc. United Kingdom 80, 675-684.

Tao, K., Robbins, J.A., Grossman, E.L., O’Dea, A., 2013. Quantifying upwelling and freshening in nearshore tropical American environments using stable isotopes in modern gastropods. Bull. Mar. Sci. 89, 815-835. doi:10.5343/1

Thompson, P.R., 2007. DSDP Volume LXVII 9. FORAMINIFERS OF THE MIDDLE AMERICA TRENCH. doi:doi:10.2973/dsdp.proc.67.109.1982

Thompson, S.A., Sydeman, W.J., Santora, J.A., Black, B.A., Suryan, R.M., Calambokidis, J., Peterson, W.T., Bograd, S.J., 2012. Linking predators to seasonality of upwelling: Using food web indicators and path analysis to infer trophic connections. Prog. Oceanogr. 101, 106-120. doi:10.1016/J.POCEAN.2012.02.001

Trebilco, R., Baum, J.K., Salomon, A.K., Dulvy, N.K., 2013. Ecosystem ecology: size-based constraints on the pyramids of life. Trends Ecol. Evol. 28, 423-431. doi:10.1016/J.TREE.2013.03.008

Tripp-Valdez, A., Galván-Magaña, F., Ortega-García, S., 2010. Feeding habits of dolphinfish (Coryphaena hippurus) in the southeastern Gulf of California, Mexico. J. Appl. Ichthyol. 26, 578582. doi:10.1111/j.1439-0426.2010.01483.x

Trueman, C.N., Johnston, G., O’Hea, B., MacKenzie, K.M., 2014. Trophic interactions of fish communities at midwater depths enhance long-term carbon storage and benthic production on continental slopes. Proc. R. Soc. B 281, 10140669. doi:10.1098/rspb.2014.0669 
1171

Vander Zanden, M.J., Rasmussen, J.B., 1999. Primary consumer $\delta^{13} \mathrm{C}$ and $\delta^{15} \mathrm{~N}$ and the trophic position of aquatic consumers. Ecology 80, 1395-1404.

Varela, J.L., Lucas-Pilozo, C.R., González-Duarte, M.M., 2017. Diet of common dolphinfish (Coryphaena hippurus) in the Pacific coast of Ecuador. J. Mar. Biol. Assoc. United Kingdom 97, 207-213. doi:10.1017/S0025315416000175

Vokhshoori, N.L., Larsen, T., McCarthy, M.D., 2014. Reconstructing $\delta^{13} \mathrm{C}$ isoscapes of phytoplankton production in a coastal upwelling system with amino acid isotope values of littoral mussels. Mar. Ecol. Prog. Ser. 504, 59-72. doi:10.3354/meps10746

Waser, N.A.D., Harrison, W.G., Head, E.J.H., Nielsen, B., Lutz, V.A., E. Calvert, S., 2000. Geographic variations in the nitrogen isotope composition of surface particulate nitrogen and new production across the North Atlantic Ocean. Deep Sea Res. Part I Oceanogr. Res. Pap. 47, 12071226. doi:10.1016/S0967-0637(99)00102-8

West, J.B., Bowen, G.J., Cerling, T.E., Ehleringer, J.R., 2006. Stable isotopes as one of nature's ecological recorders. Trends Ecol. Evol. 21, 408-414. doi:10.1016/J.TREE.2006.04.002

Wexler, J.B., Chow, S., Wakabayashi, T., Nohara, K., Margulies, D., 2007. Temporal variation in growth of yellowfin tuna (Thunnus albacares) larvae in the Panama Bight, 1990-97. Fish. Bull. $105,1-18$.

Wickham, H., 2016. ggplot2: Elegant Graphics for Data Analysis. Springer-Verlag.

Williams, S.M., Holmes, B.J., Pepperell, J.G., 2015. The Novel Application of Non-Lethal Citizen Science Tissue Sampling in Recreational Fisheries. PLoS One 10, e0135743. doi:10.1371/journal.pone.0135743

Woodland, R.J., Rodríguez, M.A., Magnan, P., Glémet, H., Cabana, G., 2012. Incorporating temporally dynamic baselines in isotopic mixing models. Ecology 93, 131-144. doi:10.1890/11-0505.1

Wu, J.P., Calvert, S.E., Wong, C.S., 1999. Carbon and Nitrogen Isotope Ratios in Sedimenting Particulate Organic Matter at an Upwelling Site off Vancouver Island. Estuar. Coast. Shelf Sci. 48, 193-203. doi:10.1006/ECSS.1998.0409 


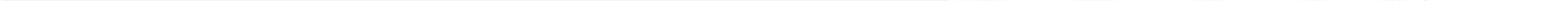



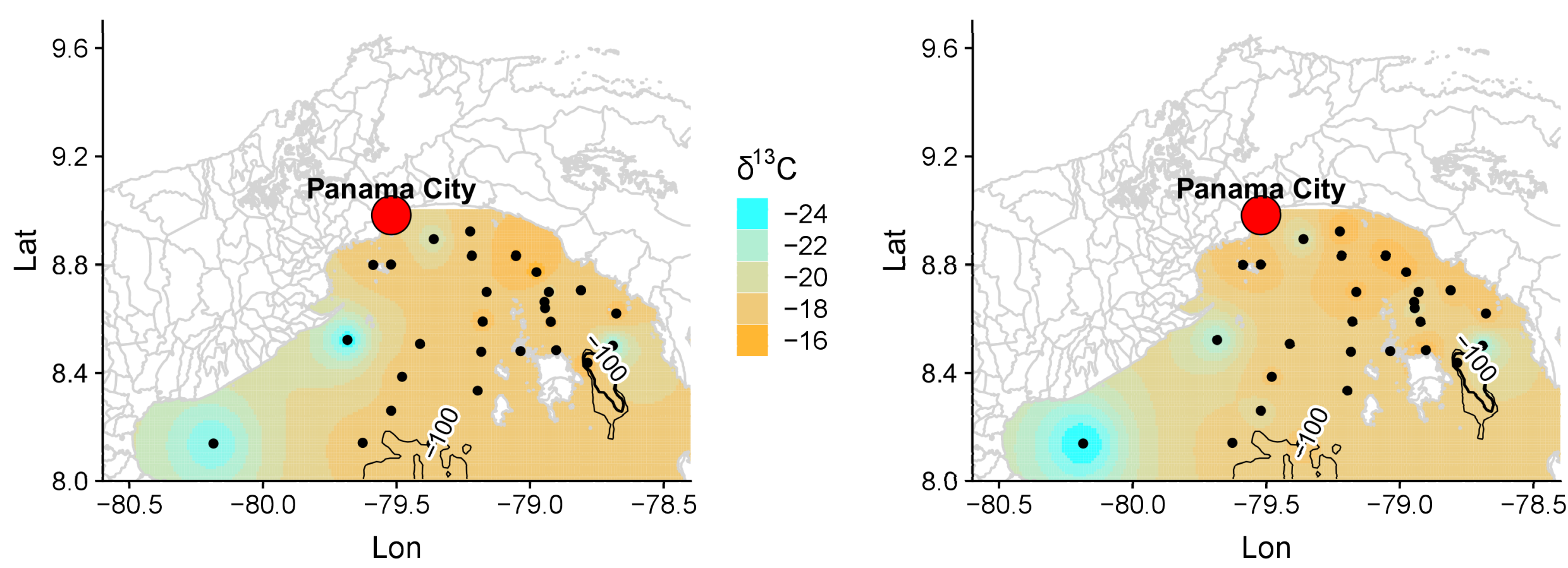

$\delta^{15} \mathrm{~N}$

C

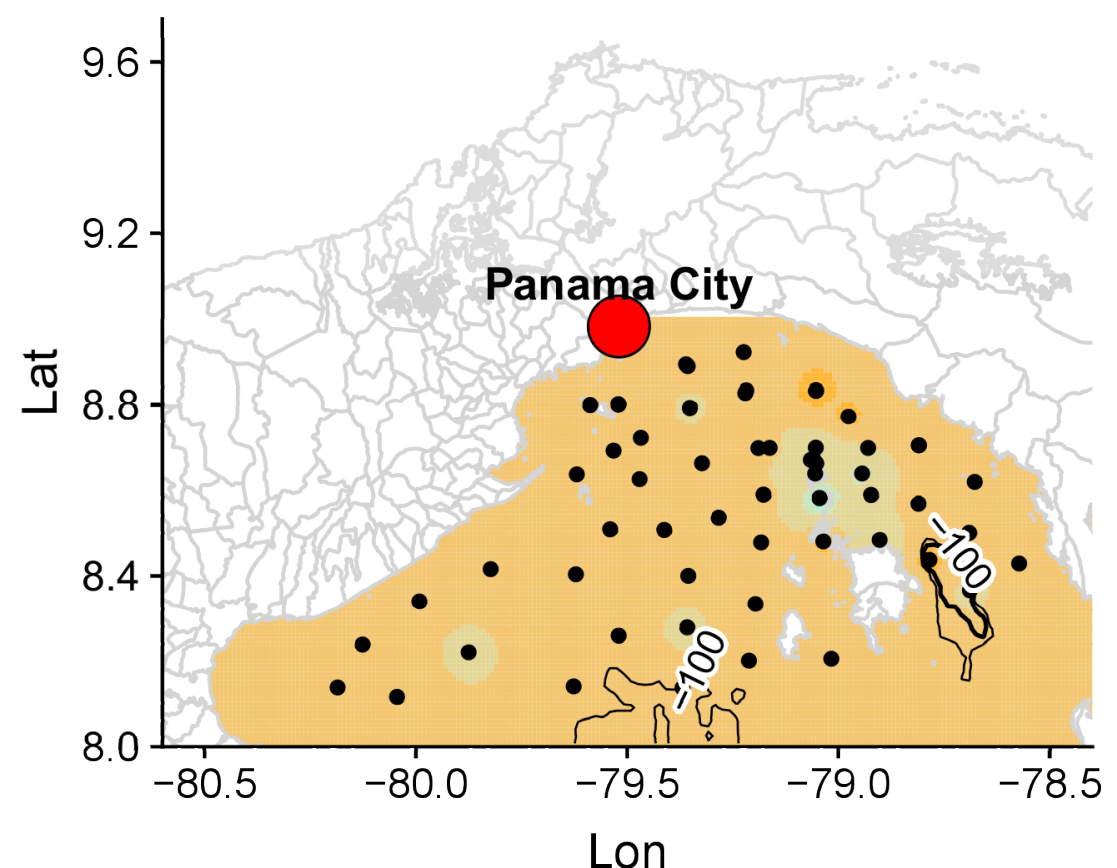

$\delta^{13} \mathrm{C}^{\prime}$

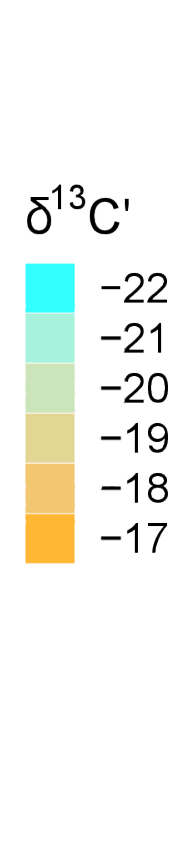

D

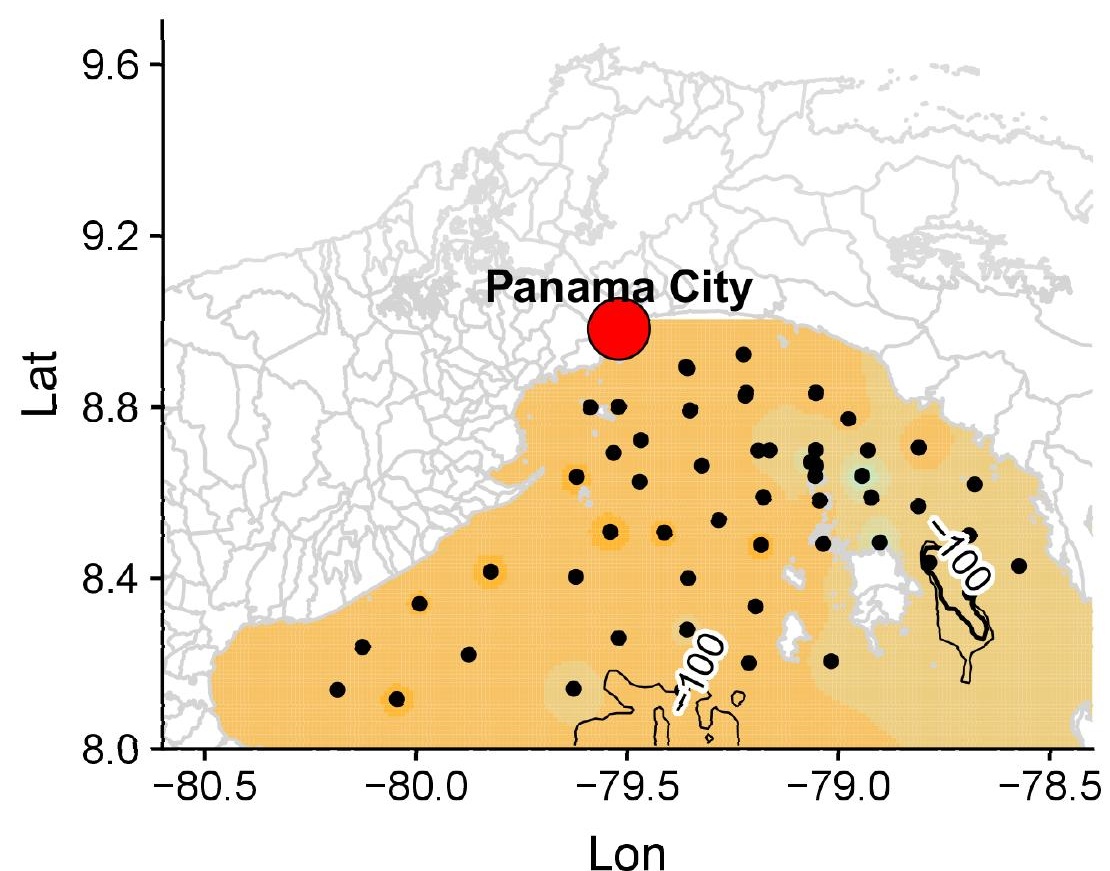

$\delta^{15} \mathrm{~N}$

4

6

10 

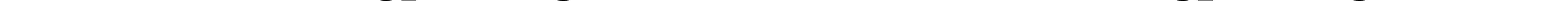


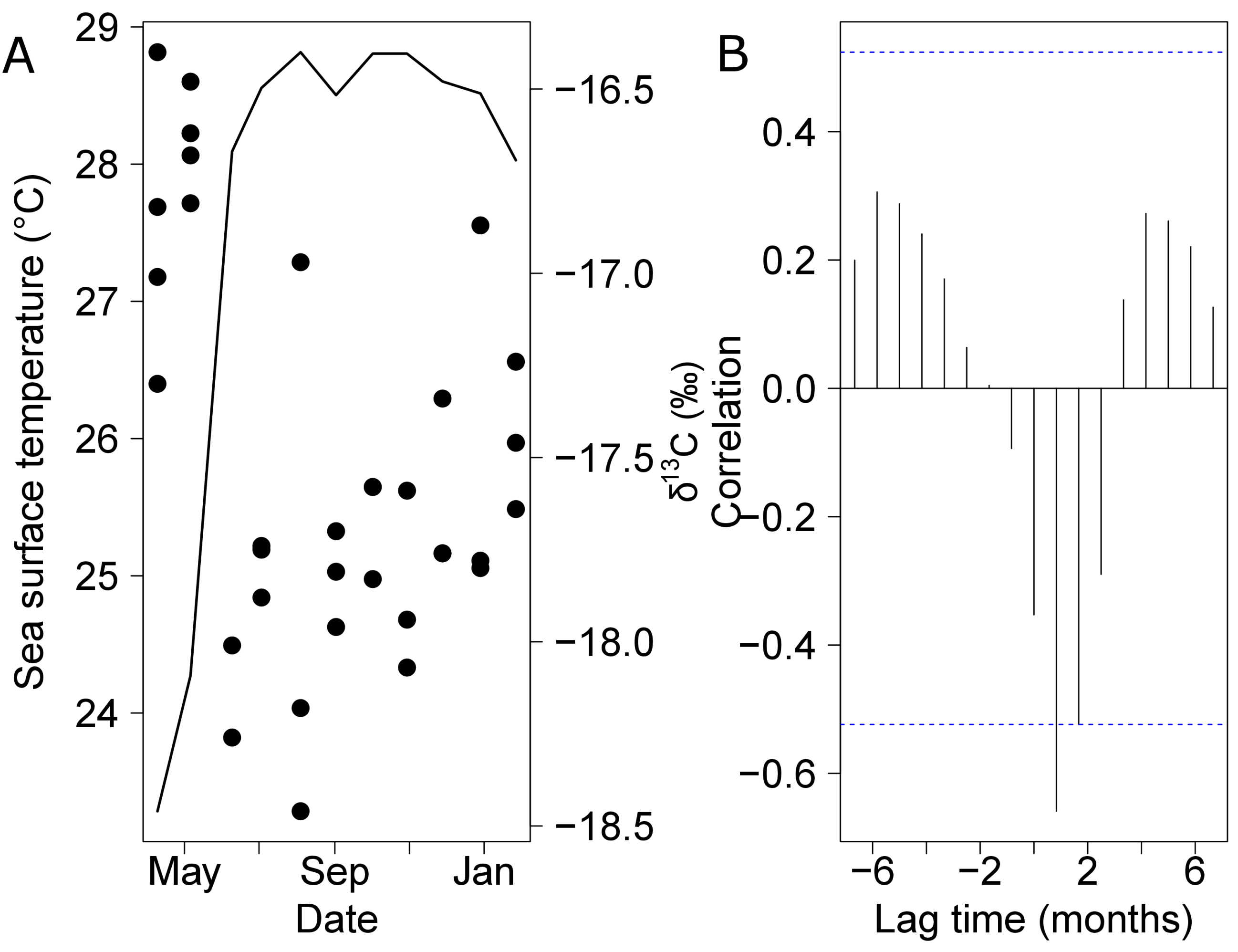




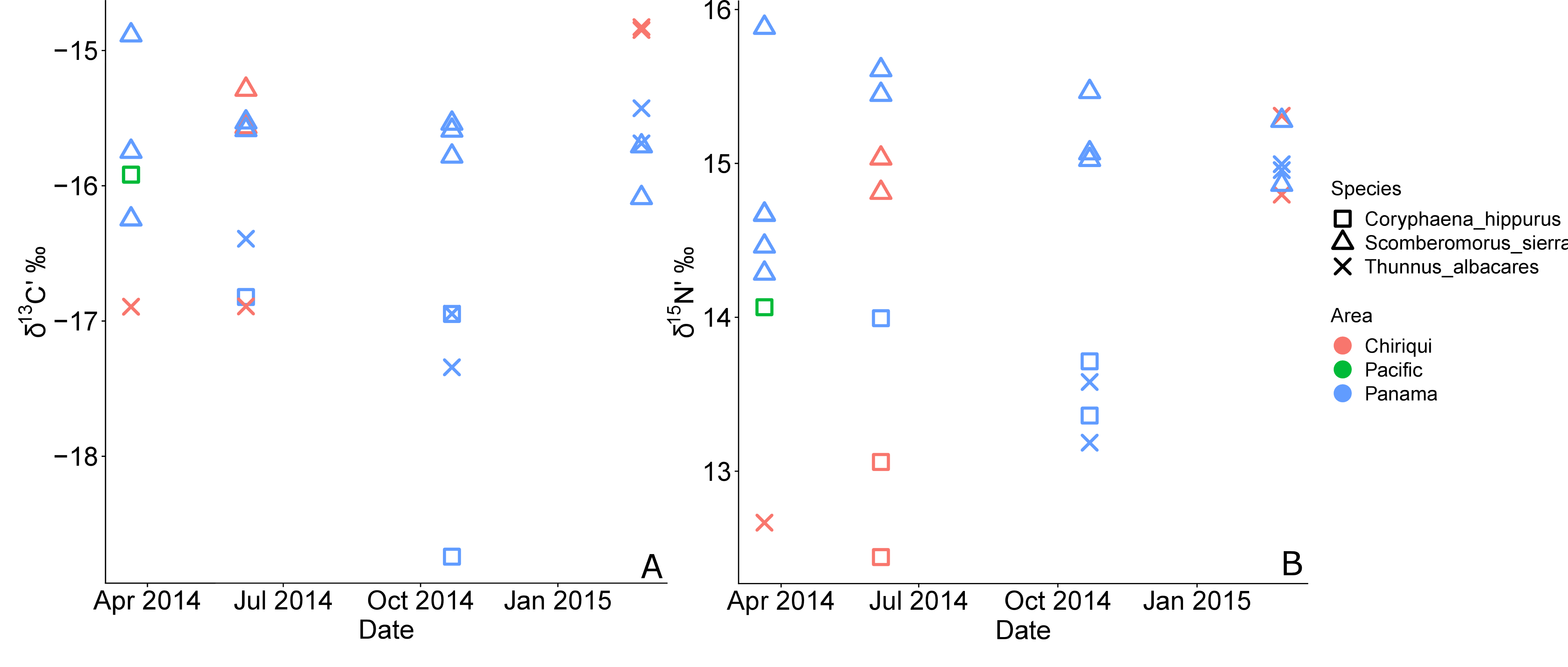

